\title{
How to counter organisational inertia to enable knowledge management practices adoption in public sector organisations
}

Article

Accepted Version

Ashok, M. ORCID: https://orcid.org/0000-0002-9827-9104, Al Badi Al Dhaheri, M. S. M., Madan, R. and Dzandu, M. D. (2021) How to counter organisational inertia to enable knowledge management practices adoption in public sector organisations. Journal of Knowledge Management, 25 (9). pp. 2245-2273. ISSN 1367-3270 doi: https://doi.org/10.1108/JKM09-2020-0700 Available at https://centaur.reading.ac.uk/95994/

It is advisable to refer to the publisher's version if you intend to cite from the work. See Guidance on citing.

To link to this article DOI: http://dx.doi.org/10.1108/JKM-09-2020-0700

Publisher: Emerald

All outputs in CentAUR are protected by Intellectual Property Rights law, including copyright law. Copyright and IPR is retained by the creators or other copyright holders. Terms and conditions for use of this material are defined in the End User Agreement. 


\section{CentAUR}

Central Archive at the University of Reading

Reading's research outputs online 


\title{
How to counter organisational inertia to enable knowledge management practices adoption in public sector organisations
}

\author{
Dr Mona Ashok ${ }^{\mathrm{a} *}$ and Dr Mouza Saeed Mohammed Al Badi Al Dhaheri ${ }^{\mathrm{b}}$ and \\ Rohit Madan ${ }^{\mathrm{a}}$ and Dr Michael D. Dzandu ${ }^{\mathrm{c}}$
}

${ }^{a}$ Business Informatics, Systems, and Accounting, Henley Business School, University of Reading, UK; ${ }^{b}$ Knowledge Systems Department, Human Resources Authority, UAE; ${ }^{c}$ Centre for Digital Business Research, Westminster Business School, University of Westminster, UK

* Email: m.ashok@henley.ac.uk corresponding author

Dr Mona Ashok is a Lecturer in Operations Management at Henley Business School, UK. She has extensive industry experience, having worked at senior management level in global IT and BPO organisations, and Accounting firm. She has worked with customers in Asia, Australia, Europe and Northern America. Mona's experience in Higher Education includes working with doctoral, postexperienced postgraduate and undergraduate programme members. Her professional and academic projects cover topics such as: process improvement, programme management, knowledge management, financial management, organisational transformation, and management consulting.

Dr Mouza Al Badi is Knowledge Systems Department Manager at Human Resources Authority, Abu Dhabi, UAE. She has extensive experience in both knowledge management and strategic fields. Mouza is an expert negotiator leading teams in complex dealings, and building close-knit workgroups, fostering collaboration, tirelessly bridging class and culture. She has been a member of The Cultural Committee of UNESCO (Middle East) from 2012- 2015 and Shaikh Mohamed Bin Khalid Cultural Centre from 1997 till present.

Rohit Madan is a PhD student at Henley Business School, University of Reading conducting research on innovation management in public sector environments. Prior to pursuing a doctorate, Rohit has extensive experience in management consulting, project management, and technology deployments in both public and private sector organisations.

Dr. Michael D. Dzandu is a Research Fellow in Digital Business at the University of Westminster, UK. His research interest spans technology, culture and human behaviour. His current research activities are in the areas of ontology, data and information modelling, digital twins and Industry 4.0 technologies. He 
holds a PhD in Business Informatics and his $\mathrm{PhD}$ research was in context-based information systems for knowledge activities, with theoretical foundations in Semiotics and the Theory of Human Behaviour.

DOI (10.1108/JKM-09-2020-0700) 
How to counter organisational inertia to enable knowledge management practices adoption in public sector organisations

Dr Mona Ashok ${ }^{\mathrm{a} *}$ and Dr Mouza Saeed Mohammed Al Badi Al Dhaheri ${ }^{\mathrm{b}}$ and Rohit Madan ${ }^{\mathrm{a}}$ and Dr Michael D. Dzandu ${ }^{\mathrm{c}}$

\begin{abstract}
Purpose: Knowledge management (KM) is associated with higher performance and innovative culture; KM can help public sector to be fiscally lean and meet diverse stakeholders' needs. However, hierarchical structures, bureaucratic culture and rigid processes inhibit KM adoption and generate inertia. This study explores the nature and causes of this inertia within the context of UAE public sector.
\end{abstract}

Methodology/approach: Using an in-depth case study of a UAE public sector organisation, this study explores how organisational inertia can be countered to enable knowledge management adoption. Semi-structured interviews are conducted with 17 top- and middle-level managers from operational, management and strategic levels. Interview data is triangulated with content analysis from multiple sources, including the UAE government and case organisation documents.

Findings: The results show transformation leadership, external factors, and organisational culture mediate the negative effect of inertia on $\mathrm{KM}$ practices adoption. We find that information technology plays a key role in enabling knowledge creation, access, adoption and sharing. Furthermore, we uncover a virtuous cycle between organisational culture and KM practices adoption in public sector. In addition, we develop a new model (relationship between KM practices, organisational inertia, organisational culture, transformational leadership traits and 
external factors), and four propositions for empirical testing by future researchers. We also present a cross-case comparison of our results with six private/quasi-private sector cases who have implemented KM practices.

Originality/value: Inertia in public section is a result of bureaucracy and authority bounded by the rules and regulations. Adopting a qualitative methodology and case study method, the research explores the phenomena of how inertia impacts KM adoption in public sector environments. Our findings reveal the underlying mechanisms of how internal and external organisational factors impact inertia. Internally, supportive organisational culture and transformational leadership traits positively effect KM adoption, which in turn has a positive effect on organisational culture to counter organisational inertia. Externally, a progressive national culture, strategy, and policy can support a knowledge-based organisation that embraces change. This study develops a new model (interactions between internal and external factors impacting KM practices in public sector), four propositions and a new two-stage process model for $\mathrm{KM}$ adoption in public sector. We present a case-comparison of how the constructs interact in a public sector as compared to six private/quasi-private sector cases from literature.

Keywords: knowledge management practices; organisational inertia; organisational culture; public sector; transformation leadership.

\section{Introduction}

Organisational research in knowledge management (KM) has generally focussed on its drivers and impacts on organisational performance (Giampaoli, Ciambotti, and Bontis 2017; Yang, Watkins, and Marsick 2004). KM practices have been shown to drive efficiency, sustainability, and innovation within governmental agencies (Osborne et al. 2015; Nonaka et al. 2014; Nonaka, 
Von Krogh, and Voelpel 2006). With an increasing interest in seeking new approaches to weather rapidly changing external environments and fiscal austerity, public sector is implementing KM practices to enhance service delivery and performance (Moffett and Walker 2015; Richards and Duxbury, 2015; Al Ahbabi et al. 2019).

KM practices represent a radical change in the structure and culture of the organisations (Ashok, Narula, and Martinez-Noya 2016). Literature highlights several barriers to change in the public sector such as bureaucratic culture, political processes, rigidity, and employee resistance (Taylor and Wright 2004; Tremml 2020; Wankhade, Heath, and Radcliffe 2018). However, empirical research on the KM practices implementation is limited (Valmohammadi and Ahmadi 2015). Zahedi, Shahin, and Ali Babar (2016) systematic literature review of knowledge sharing practices reveals a greater propensity of researchers to report work practices than implementation challenges. A lack of an accurate understanding and challenges of KM practices adoption in relation to organisational inertia, especially in the public sector context (Frost 2014; Cong, Pandya, and Duan 2004), has resulted in failed implementations with limited benefits realisation (Al-Khouri 2014; Kim et al. 2014; Greco, Grimaldi, and Hanandi 2013).

In response to this research gap, this study explores the phenomenon of KM practices and investigates the impact of organisational inertia on its adoption within a public sector organisation in the United Arab Emirates (UAE). The key objective is to ascertain whether and how organisational culture and senior executives' leadership traits reduce the negative impact of organisational inertia on KM practices adoption in the public sector context. The study contributes to the literature on how public sector organisations can serve their customers more effectively by focusing on knowledge culture. 
The study is contextualised within the UAE that launched 'Vision 2021' in 2010 to achieve a higher non-oil real GDP growth, increase innovation, and enhance research and development (UAE 2020). As a result, UAE public sector has witnessed a growing interest in developing knowledge-based organisations (Al-Khouri 2014; Al-Ammary 2008). Public sector environment is unique and context-specific where stakeholders and accountabilities differ significantly from private sector (Arora 2011; Tremml 2020). Thus, KM practices from the private sector may not be easily replicated in the public sector without taking into consideration the cultural and organisational structure aspects (UNPAN 2007).

In response to the research gaps, this study explores two research questions:

How does organisational inertia impact KM practices adoption in public sector?

How does organisational culture and senior executives' leadership traits impact the relationship between KM practices adoption and organisational inertia in public sector?

This study uses an exploratory qualitative research approach to collect data from a public sector Educational Administration body in Abu Dhabi. Using an in-depth single case research design and multiple sources of data for triangulation (Bryman and Bell 2007) similar to the approaches used by Soo, Chen, and Edwards (2018); Ann Hazlett, McAdam, and Beggs (2008), a conceptual model is developed exploring the relationship between KM practices adoption, organisational inertia, organisational culture, and senior executives' leadership traits and validated with cross-case comparisons of public and quasi-public sector organisations. The results show transformation leadership, external factors, and organisational culture mediate the negative effect of inertia on KM practices adoption. Furthermore, we uncover a virtuous cycle between organisational culture and KM practices adoption in public sector. Four propositions are developed 
for empirical testing and a Process Model for KM Practices Adoption in the Public Sector is proposed for practitioner applications.

The rest of the paper covers the literature review and the theoretical model. This is followed by the research methodology used in the study, the findings, and the conceptual model. Further, the findings and the conceptual model are validated using a cross-case comparison followed by a discussion and contribution section. The paper ends with conclusion, limitations and highlights of future research opportunities.

\section{Literature Review and Theoretical Model}

Knowledge management is defined as 'a capability to leverage (internal and external) knowledge to enable superior performance, encourage innovation and enhance customer value' (Ashok, Narula, and Martinez-Noya 2016, 1008). KM practices refers to the actions of generation, codification, and transfer of organisations' knowledge with the aim to improve performance and support decision-making (Hlupic, Pouloudi, and Rzevski 2002; Gold, Malhotra, and Segars 2001). Huysman and de Wit (2004) cross-case analysis of knowledge sharing practices among 10 large organisations reveals three main traps. First, management trap characterised by opportunity and control bias as opposed to building sharing practices as part of day-to-day work. Second, local learning trap characterised by operational and individual level learning as opposed to an organisation-wide social capital building. Third, ICT trap characterised by codification of best practices and focus on technology than personal networks and other forms of knowledge.

Scholars contends knowledge need not be limited to best practices and discuss various dimensions such as "explicit" and "tactical" (Smith Elizabeth 2001, 314) or "professional", “coordination”, “object-based”, "know-how” (Holdt Christensen 2007, 37). 
$\mathrm{KM}$ practices in public sector can drive efficiency, improve decision-making, and enhance policy development, service delivery, and effectiveness (Birkinshaw and Sheehan 2002; Pee and Kankanhalli 2016). Hsu and Lin (2008) stressed organisational human capital is enriched by knowledge sharing practices that improves employees' competencies and organisational efficiency. Previous studies have provided empirical evidence on the benefits of KM practices in the public sector. For example, in the Malaysian public sector, researchers point to the need for knowledge sharing and exchange to drive value (Kasim 2008; Dimitriades 2005). Research shows the importance of KM in driving better economic growth and improved equity in the Indian public sector (Chawla and Joshi 2010). Abass et al. (2011)'s study on Pakistani public sector showed a significant interrelationship between KM practices and the complexity of organisational practices.

Literature discusses two imperative drivers of KM practices in the public sector: first, 'human capital crisis' resulting from retirements, attritions, and privatisation calling for an urgent need to prevent loss of tactic knowledge and second, proliferation of information technology requiring strong capabilities for knowledge generation and sharing (Choi and Chandler, 2020; Pee and Kankanhalli 2016; Misra, Hariharan, and Khaneja 2003). Researchers have indicated the importance of cultural change readiness in driving effective KM practices adoption (Taylor and de Loë 2012; Rusly, Corner, and Sun 2012). Establishing and promoting a knowledge culture in the public sector is challenging given its ambiguous and conflicting goals (Boyne 2002; Julnes and Holzer 2001; Rainey and Bozeman 2000).

Previous studies have explored the relationship between KM practices adoption and organisational inertia, culture, and senior executives' skills in separate settings (Boateng, Dzandu, and Tang 2016; López-Nicolás and Meroño-Cerdán 2011). However, none of these 
studies specifically investigate how organisational culture and senior executives' leadership influence the relationship between organisational inertia and KM practices adoption. This study fills this gap by exploring the relationships between these four constructs in the UAE public sector context.

This section discusses organisational change theories to ground KM practices adoption as a radical change within public sector organisations. This is followed by a discussion on organisational inertia, transformational leadership, and organisational culture as key constructs used in the design of interview protocols and template analysis.

\subsection{Organisational change}

Hannan and Freeman (1984) discuss three main theories of organisational change: population ecology, rational adaptation, and random transformation. Van de Ven and Poole $(1995,511)$ 's literature review on organisational change outlines four ideal-type theories termed as 'motors': lifecycle, teleology, dialectics, and evolution. They argue these motors can explain most contextspecific change theories. Kuipers et al. (2014) shows institutional theory and change management theory as the most frequently employed theoretical framework in public sector change literature. Institutionalists argue change is impelled by exogenous processes and tenuously related to strategic efforts of its leaders conforming to random transformation (DiMaggio and Powell 1983). Change management theory on the other hand conforms with rational adaptation principles positing organisational change is driven by intentional actions of its agents (Fernandez and Rainey 2006). This study adopts a rational adaptation framework driven by lifecycle and teleology motors to explore KM practices adoption as change engendered by organisation and process innovation; organisational inertia is discussed employing population 
ecology theory. Furthermore, this study falls in the change management theoretical cluster postulating the intentional role of political and administrative leadership in driving change.

The traditional public sector organisational structure is based on Weber's bureaucracy model with a top-down hierarchy designed to deliver stable and accountable services engendering citizen trust (Hartley, Sørensen, and Torfing 2013; Kattel et al. 2014). Christensen et al. (2007) discusses two cultural perspectives of public sector organisations: instrumental and institutional. Instrumental perspective is driven by expected future effects and leaders are considered as drivers of organisational culture (ibid.). On the other hand, institutional perspective relates to individuals acting in accordance with their past experience and judgement of fair and reasonable behaviour in a cultural context (ibid.).

The instrumental perspective, based on rational adaptation, has been dominant in research and practice. For instance, New Public Management (NPM) reforms based on an instrumental perspectives advocating adoption of private sector market control mechanisms and implementation driven by political and administrative leadership has been with limited success (Torfing 2019). For example, Parker (2000)'s examination of six public sector organisations in Australia that implemented NPM reforms found these organisations continued to emphasise values of hierarchical and bureaucratic culture explicating a strong institutional character. We explore organisational inertia acknowledging institutional disposition of public sector organisations.

\subsection{Organisational inertia}

Rumelt $(1995,3)$ defines organisational inertia as a 'strong persistence of existing form and function' and discusses two main theoretical perspectives as 'organisational ecology' and 'evolutionary economics'. The ecological perspective follows Hannan and Freeman (1984)'s 
definition of inertia as impeding internal change relative to a faster external change. Their propositions stem from population ecology that postulates reliability and accountability are vital for organisational survival with a downside of creating inertia to change (ibid.). Leonard-Barton (1992) discuss core capabilities as 'a set of differentiated skills, complementary assets, and routines that provide the basis for a firm's competitive capacities and sustainable advantage' (Teece, Pisano, and Shuen, 1990:28 as cited in Leonard-Barton 1992, 121). Core capabilities are institutionalised and taken for granted reality resulting in inertia requiring creative destruction (Schumpeter 1942) to implement change and build new capabilities. Hannan and Freeman (1984) also argue inertia is highest for changes to core capabilities and decreasing in strength for more peripheral capabilities such as marketing. In the context of public sector, geographic and national political pressures, bias and employee frustrations are manifestations of organisational inertia, which leads to poor organisational performance (Choi and Chandler, 2020).

The evolutionary economics perspective has its roots in bounded rationality (Simon 1972; Simon 1991) and status quo bias in decision-making (Samuelson and Zeckhauser 1988) which leads to deviations from rational choice models that predict organisations will adapt optimally to external change for value maximization. Andrews, Boyne, and Enticott (2006)'s empirical study of public sector performance failures contend both adaptationist (rational adaptation) and selectionist (ecology) principles at play.

Clark (2005) expands on these perspectives by elaborating two distinct forms of organisational inertia: 'resource rigidity' and 'routine rigidity'. Resource rigidity is derived from 
resource dependency theory that states resource providers ${ }^{1}$ limit internal strategic choices and existence of an inherent status quo bias causing friction to initiate a change. Routine rigidity relates to deeply entrenched processes that are 'self-reinforcing through structural embeddedness and repeated use' (Clark 2005, 742) and causes friction during implementation.

Public sector organisations face challenges in driving KM effectiveness due to organisational inertia (Taylor and Wright 2004). Resource and routine rigidity is prevalent as a result of bureaucracy and hierarchy, rigid policies and procedures, internal politics, and status quo bias (OECD 2003). Empirical studies in KM (Yew Wong 2005; Khalifa and Liu 2003) have largely focused on the role of technology (Huysman and Wulf 2006; Albino, Garavelli, and Gorgoglione 2004) and innovation and creativity (Ing-Long and Ya-Ping 2018; Ashok, Narula, and Martinez-Noya 2016). There is a gap in literature specifically on how organisational inertia impacts KM practices adoption in public sector organisations, where information technology plays an enabling role.

Organisational inertia compromises the firm's agility and responsiveness, hampers learning from new knowledge and technology, and creates rigidity ( Bannister and Connolly, 2020; Ashok, Narula, and Martinez-Noya 2014). Taher, Krotov, and Silva (2015) highlight change within the UAE public sector is inhibited by inertia caused by a lack of organisational stability, bureaucracy, traditions, lack of management commitment, poor communication, fear of losing power, lack of technological skills, and job security.

\footnotetext{
${ }^{1}$ In public sector organisations, resource providers are central political agencies that control budgets and limit strategic choices for administrative leadership.
} 


\subsection{Senior executives' transformational leadership traits}

Burns (1978) was the first to conceptualise transformational and transactional leadership based on a descriptive research of political leaders. This paper focusses on transformational leadership exploring how public sector leaders influence their followers to 'rise to higher levels of motivation and morality' (Burns, 1978, 20) to develop a knowledge culture. Transformational leadership is associated with four higher level constructs: idealized influence garnering respect and trust; inspirational motivation garnering intrinsic motivational drivers; intellectual stimulation towards innovation and creativity; and, individualized consideration, caring for employees and acting as a coach (Wright and Pandey 2010; Bass et al. 2003).

Transformation leadership in public sector is critical to lead organisational change and knowledge transformation (Mahoney 2000; Hansen and Pihl-Thingvad 2019; Ricard et al. 2017). Rosing, Frese, and Bausch (2011) concurs with transformational leadership being the most strongly suggested leadership type related to innovation and change. Adeinat and Abdulfatah (2019) argue transformation leadership skills to motivate and influence employees are critical success factors for KM adoption in education sector.

Waterhouse and Lewis (2004) explicates limited success of a public sector organisation to change the bureaucratic culture towards an open knowledge culture resulting from the inability to address the needs of the employees for an inspiring vision and direction. Scholars contend successful change needs to be institutionalised in the corporate culture through communication, vision, trust, and senior management personification of the new approach (Yang and Maxwell, 2011; Kotter 1995). Van der Voet, Kuipers, and Groeneveld (2016) show transformational leadership indirectly influences employee's affective commitment to change by enhancing the occurrence of change processes. 
KM adoption starts with transformational leadership fostering cultural change, promoting trust, investing in technology, and motivating individuals to adopt KM practices (Taylor and de Loë 2012; Rusly, Corner, and Sun 2012).

\subsection{Organisational culture}

Schein $(2006,17)$ defines organisational culture as 'a pattern of shared basic assumptions that was learned by a group as it solved its problems of external adaptation and internal integration, that has worked well enough to be considered valid.' Schein (1992) multilevel model of culture consists of core values as basic underlying assumptions that are invisible but a powerful determinant of individual and group behaviour. These determine how people perform their duties, interact with others, and embrace change. Cultural change takes time and requires transformational leadership and employee commitment (Schraeder, Tears, and Jordan 2005; Gatenby et al. 2015). Organisational culture plays a critical role in delivering a successful KM implementation and creating a knowledge-based organisation (Yang and Maxwell, 2020; Taylor and Wright 2004). However, there is limited evidence in literature on how organisational culture can be used to minimise the organisational inertia toward KM practices adoption in public sector in the Middle East.

A knowledge culture supports continuous learning cycles and forward-looking organisational practices that enables innovation (Ashok, Day, and Narula 2018; Gruman and Saks 2011). Employees are the internal source of knowledge and know-how in organisations and contribute to its knowledge base. Van der Voet, Kuipers, and Groeneveld (2016) concurs showing employee communication and participation supports change commitment. Therefore, employees' involvement in KM practices is critical to organisations looking to deliver value (Vestal 2012; Ardichvili et al. 2006). In this regard, researchers have pointed to the importance 
of fostering a culture of knowledge sharing among individuals (Henttonen, Kianto, and Ritala 2016; Tan and Wong 2015). Competing values framework shows cultural archetypes of adhocracy (characterised by values of empowerment, experimentation, autonomy) are favourable in supporting innovation and change (Cameron and Quinn 2006).

Bansler and Havn (2003) case study of a failed knowledge management system in a large organisation identifies cultural barriers to adoption such as preference of personal networks for knowledge sharing, sharing outside of networks associated with bragging. Park, Park, and Ryu (2013) shows cultural nuances in Asian countries with formal structures associated with positive organisational commitment, and hence motivation towards change, contradictory to findings in Western nations. Leading studies in KM and organisational culture have been conducted in Western economies leaving a gap in the understanding of the concepts in developing (especially Arab) countries (Pauleen, $\mathrm{Wu}$, and Dexter 2007). UAE culture is mainly influenced by two factors: Islamic values and tribal traditions. Emirati culture ranks high on Hofstede's power distance and is categorised as a collectivistic society with high uncertainty avoidance explicating a rigid code of conduct and rules (Insights 2020). Culture has a deep impact on the way individual's process information and knowledge within organisations.

\subsection{Theoretical model}

The theoretical model based on the literature review shows the expected relationship between the four constructs to be explored in this study (Figure 1). The study aims to understand the complex phenomenon of KM practices adoption in public sector context and its underlying relationships with organisational inertia, organisational culture, and senior executives' leadership skills.

Figure 1: Theoretical Model 


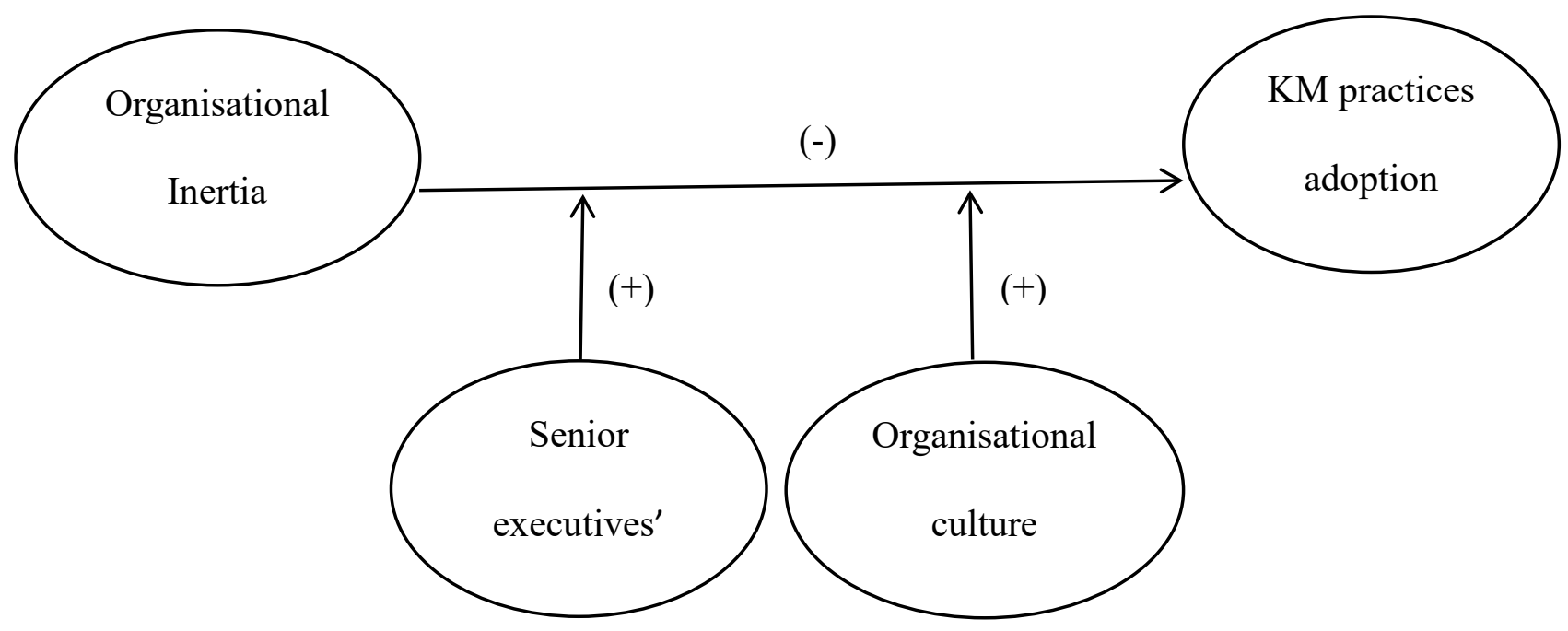

\section{Research Methodology}

This exploratory research used qualitative methods to gain a deeper understanding of the factors influencing KM practices adoption within public sector organisations. The research approach followed 7-steps suggested by Gummesson (2008) when using a case study method (Yin 2015). Scholarly work in KM in public sector has adopted similar in-depth case study methodology (Soo, Chen, and Edwards 2018; Ann Hazlett, McAdam, and Beggs 2008), especially in the higher education sector (Adeinat and Abdulfatah 2019; Cranfield and Taylor 2008). A single case organisation enabled comprehensive access to explore the phenomenon from different perspectives (Bryman 2016). Further, Ashworth, McDermott and Currie (2019) argue that qualitative research that combines rigour and richness enables significant contribution to theory, especially in the field of public administration. Thus, this study used multiple sources of data (primary and secondary) to reduce bias and improve validity and reliability of the results.

UAE's pursuit of a knowledge-based economy diversified from its dependence on oil revenues provides a rare context for our research questions. UAE's 'Vision 2021' expressed as 'United in knowledge' reflects its belief in building its innovation capabilities through promotion 
of KM practices (Forum 2016). In line with this vision, public sector organisations have adopted various KM initiatives, such as, ‘Ask an Expert', 'E-Judge System', 'and Government Expertise'.

Educational sector characterised by learning-by-doing approach and limited innovation and experimentation has been associated with "structurally" and "normatively" unfavourable to knowledge sharing practices (OECD 2002). UAE's educational sector needs to play a key role in achieving a knowledge-based economy through driving an ambitious ten-year vision to improve the quality of education and perform above the international standards (UAE's 'Vision 2021'). Standard procedures were used to approach the Ministry of Education in UAE to identify potential research case organisations. The selected case, set within UAE's public sector, agreed to participate in the research and senior management enabled researchers' engagement with potential research participants. The case organisation is responsible for education administration of a region. The organisation not only focusses on the latest trends in education pedagogy, curriculum, teachers' skills but also assimilation of national culture and learnings from other nations. In addition to serving teacher and students, the organisation helps investors establish educational institutions in the region. The organisation's workforce includes 700 employees, 5 executive directors, 34 divisional senior executive managers, and 65 section managers. Thus, an educational sector public organisation provides an ideal context for exploring our constructs not only within a public sector organisation with a closed bureaucratic culture but also situated within a sector adopting KM practices with the objective of improving performance and transitioning towards an open knowledge national culture.

Purposive and snowball sampling (Denscombe 2007) were used to select interview participants. Out of 54 managerial executives who were contacted, 17 agreed to take part in the 
study and participated in one-hour interview sessions. Semi-structured interviews were used to collect rich data about the phenomenon while ensuring completeness and structure (Daymon and Holloway 2011; Rubin and Rubin 2011). All the interviews were conducted in Arabic, recorded (with participants' consent), and translated into English.

The sampled participants included five executives in top management (30\%), six in middle management (35\%), and six in operation management (35\%) (Table 1). Thus, two-thirds of the participants had management responsibilities enabling a better understanding of senior executive's role in driving KM adoption and reducing organisational inertia. Over $40 \%$ of the informants were women.

Scholars argue that case organisations should be selected where there is an opportunity to triangulate data from different sources and content analysis of in-depth documents add richness to the study (Moynihan, 2009). Thus, this study triangulated interview data with content analysis from multiple sources, including the UAE government and case organisation documents.

Data analysis followed a clear structure, interviews were transcribed, coded, and analysed using Nvivo. Documents were also analysed using Nvivo. The results showed the relationships between themes, incidences, and nodes (Braun and Clarke 2006). Three steps of thematic analysis were applied: first-order themes, second-order themes, and aggregation (King and Horrocks 2010) until theoretical saturation was achieved (Glaser and Strauss 1967). The findings were organised by themes as supported by direct quotations (Symon and Cassell 2012). Ethical consideration for the study included informed consent through full disclosure of the purpose of the study, guaranteed anonymity, interviewee safety as well as confidentiality of the case organisation. 
Table 1: Interview participants' profile

\begin{tabular}{|c|c|c|c|c|}
\hline No. & Participants designation & Gender & Position-hierarchy & $\begin{array}{l}\text { Public sector } \\
\text { experience in years }\end{array}$ \\
\hline $\mathrm{P} 1$ & Executive Director & Male & Top management & 13 \\
\hline $\mathrm{P} 2$ & Executive Manager & Female & Middle management & 11 \\
\hline P3 & Operational Manager & Female & Operations management & 12 \\
\hline $\mathrm{P} 4$ & $\begin{array}{l}\text { Business Development } \\
\text { Division Manager }\end{array}$ & Female & Middle management & 7 \\
\hline P5 & Strategy Division Manager & Male & Top management & 18 \\
\hline P6 & HR Division Manager & Male & Top management & 9 \\
\hline P7 & Senior Operational Manager & Female & Operations management & 10 \\
\hline P8 & $\begin{array}{l}\text { General Services Division } \\
\text { Manager }\end{array}$ & Male & Top management & 5 \\
\hline P9 & $\begin{array}{l}\text { School Administration } \\
\text { Division Manager }\end{array}$ & Male & Middle management & 8 \\
\hline P10 & $\begin{array}{l}\text { Customer Services Division } \\
\text { Manager }\end{array}$ & Male & Middle management & 6 \\
\hline P11 & Finance Division Manager & Female & Top management & 12 \\
\hline P12 & $\begin{array}{l}\text { Procurement and Contract } \\
\text { Management Manager }\end{array}$ & Male & Middle management & 9 \\
\hline P13 & $\begin{array}{l}\text { School Improvement } \\
\text { Division Manager }\end{array}$ & Female & Operations management & 8 \\
\hline P14 & $\begin{array}{l}\text { Business Operations } \\
\text { Manager }\end{array}$ & Male & Operations management & 7 \\
\hline P15 & $\begin{array}{l}\text { General Services Division } \\
\text { Manager }\end{array}$ & Male & Operations management & 5 \\
\hline P16 & $\begin{array}{l}\text { Policy Planning and } \\
\text { Performance Management } \\
\text { Division Manager }\end{array}$ & Female & Middle Management & 10 \\
\hline P17 & $\begin{array}{l}\text { Labour Market Intelligence } \\
\text { Division Manager }\end{array}$ & Male & Operations Management & 8 \\
\hline
\end{tabular}

\section{Findings}

The data analysis revealed 26 codes recognising 1,385 incidents illustrating the nature of the relationships between organisational inertia and $\mathrm{KM}$ practice adoption and the role of organisational culture and transformation leadership in reducing inertia. These codes were categorised into five first-order themes (T1-T5) (Table 2). The relationship between the themes 
are shown in Figure 2 adopting inductive reasoning to develop relationships amongst a priori constructs and emerging themes from the data. The following sections present the findings of the analysis.

\subsection{KM practices adoption}

The data on KM practices adoption revealed six themes (T1.1 to T1.6, Table 2). All the participants concurred these factors should be given priority during KM practices adoption. They explained the organisation should focus on sharing and utilising knowledge as a means for creating new knowledge; KM strategy should be considered as a road map to align with UAE Vision 2021. The significance of technology in facilitating knowledge access was also highlighted. Reflexivity and field notes revealed KM adoption positively impacts cultural values of innovation, empowerment, loyalty, and employee relationship. As discussed under the organisational culture theme, these values are key in minimising inertia. Thus, KM practices adoption and organisational culture were shown to form a virtuous cycle. 
Table 2: Themes and incidents from data analysis

\begin{tabular}{|c|c|l|l|}
\hline$\#$ & Nodes concept/themes & $\begin{array}{l}\text { \# of } \\
\text { interviewees }\end{array}$ & $\begin{array}{l}\text { \# of } \\
\text { incidents }\end{array}$ \\
\hline T1 & KM Practices Adoption & $\mathbf{1 7}$ & $\mathbf{4 0 4}$ \\
\hline T1.1 & Knowledge creation & 15 & 73 \\
\hline T1.2 & Knowledge development & 10 & 70 \\
\hline T1.3 & KMS and technology & 15 & 22 \\
\hline T1.4 & Knowledge sharing & 14 & 103 \\
\hline T1.5 & Knowledge strategy & 15 & 50 \\
\hline T1.6 & Knowledge utilisation & 15 & 86 \\
\hline T2 & Organisational Inertia & $\mathbf{1 7}$ & $\mathbf{1 6 6}$ \\
\hline T2.1 & Resource rigidity & 14 & 109 \\
\hline T2.1.1 & Restricted knowledge access & 14 & 58 \\
\hline T2.1.2 & National strategy and policy & 9 & 24 \\
\hline T2.1.3 & Organisational Bureaucracy & 10 & 27 \\
\hline T2.2 & Routine rigidity & 12 & 57 \\
\hline T2.2.1 & National culture & 9 & 13 \\
\hline T2.2.2 & Organisation Internal Policies & 12 & 44 \\
\hline T3 & Organisational Culture & $\mathbf{1 7}$ & $\mathbf{2 9 6}$ \\
\hline T3.1 & Adhocracy culture & 15 & 225 \\
\hline T3.1.1 & Employee empowerment & 7 & 13 \\
\hline T3.1.2 & Innovation culture & 15 & 77 \\
\hline T3.1.3 & Knowledge culture & 15 & 135 \\
\hline T3.2 & Clan culture & 14 & 71 \\
\hline T3.2.1 & Organisation loyalty & 10 & 20 \\
\hline T3.2.2 & Social context and employee's relationship & 14 & 51 \\
\hline T4 & Senior Executives' Transformational Leadership & $\mathbf{1 7}$ & $\mathbf{3 0 1}$ \\
\hline T4 & Driving change & 14 & 54 \\
\hline T4.2 & Encouragement & 14 & 56 \\
\hline T4.3 & Involvement & 15 & 99 \\
\hline T4.4 & Rewarding and motivating & 10 & 22 \\
\hline T4.5 & Trust building & 15 & 70 \\
\hline T5 & External Factors & $\mathbf{1 7}$ & $\mathbf{2 1 8}$ \\
\hline T5.1 & Political leadership & 17 & 181 \\
\hline T5.2 & National change agenda & 9 & 37 \\
\hline & & & \\
\hline & & & \\
\hline & & 17 & \\
\hline & & & \\
\hline
\end{tabular}


Figure 2: Explaining the relationship between organisational inertia, KM practices, leadership, and organisational culture

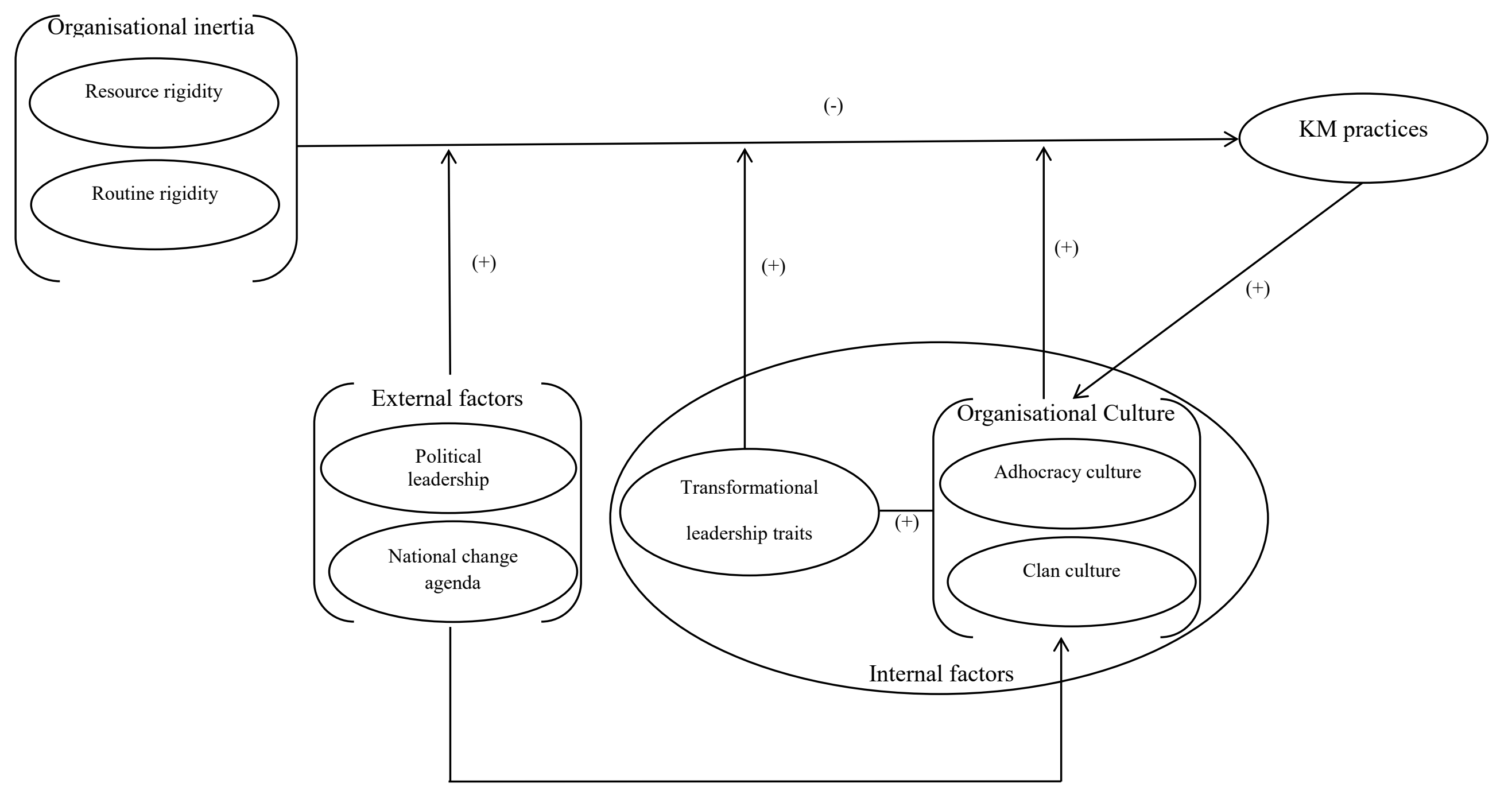

(+) 


\section{Knowledge Creation (T1.1)}

Knowledge creation comes from two sources: tacit and explicit (Nonaka 1994). Knowledge emerges from the experiences and skills of the employees and is socially constructed through interactions with others (ibid.). Creating knowledge is about solving problems, learning from past experience, conducting research, and interacting with stakeholders. The organisation should focus on motivating employees to adopt KM practices to learn and develop new skills and capabilities. The informants identified the importance of knowledge creation in KM practice adoption, for example:

Knowledge is not about building systems and sorting sets of data, it's more as a culture of creating knowledge to develop new knowledge and utilising this new knowledge in solving problems and creating new knowledge

\section{Knowledge Development (T1.2)}

Organisations should be able to store, retrieve, and share its knowledge and ensure people, processes, and technologies are appropriately developed (Probst, Raub, and Romhardt 2000). The participants highlighted the role of knowledge resource development in supporting knowledge culture, for example:

But before we talk about knowledge management practices, is important to develop our knowledge resources in term of people, processes, information and knowledge source. When you create or acquire new knowledge, the next step is to use this knowledge to solve problems and deliver new services to [the] community 


\section{KMS and Technology (T1.3)}

Most participants mentioned knowledge management systems (KMS) and technology as an important facilitator of KM practices in public sector (Choi and Chandler, 2020; Bannister and Connolly, 2020). They stated that technology provides an open channel for employees to share their knowledge and a social platform for knowledge creation through cross-office interactions, for example:

We have KMS that we use [...] on a daily basis. KMS and technology play a good role in providing a fast knowledge response. We have this internal chat application, where we use it to ask each other and discuss on different daily tasks. This is really good and the data we have exchanged in the application is stored for future retrieving

\section{Knowledge Sharing (T1.4)}

Knowledge sharing as a determinant of organisational success is extensively discussed in literature (Yeh, Lai, and Ho 2006). Wang and Wang (2012) show explicit knowledge sharing has a significant positive effect on innovation speed and financial performance and tactic knowledge sharing having a significant positive effect on innovation quality and operational performance. The participants highlighted the importance of knowledge sharing driving KM practices adoption inside their organisation. A manager elaborates on the importance of knowledge sharing as:

For sure, as I have said earlier knowledge sharing [is] important to employees to engage and share their information, knowledge, with others, to guarantee a progress in the know-how, experiences, skills, and of course this will be reflected at the organisational level through an enhanced knowledge base and performance 
Knowledge Strategy (T1.5)

The knowledge strategy needs to address knowledge practices, knowledge source management, and processes used in driving performance and achieving goals (Ramalingam 2005). The participants in relation to a clear plan for managing the organisation's KM practices adoption, for example, highlighted knowledge strategy:

We need to develop a clear strategy or a plan to deal with the organisation's knowledge... I think we need a way to control and mentor all the related issues to the knowledge management on both sides internally and externally

Knowledge Utilisation (T1.6)

Knowledge utilisation will enable public organisations to become efficient and support decisionmakers through a deeper understanding of external environments (Richards and Duxbury, 2015; Ngah and Wong 2020). The participants affirmed the necessity to fully utilise KM to enhance employees' capabilities and experiences. A manager elaborates this as:

I believe that our organisation utilises knowledge captured from different sources, to support our strategy and planning office, to take proper decisions, to develop strategies, and to overcome the challenges in our working field

\subsection{Organisational Inertia (T2)}

The inertia data revealed five sub-themes outlined by the participants as antecedents of routine and resource rigidity (T2.1 and T2.2, Table 2). The participants acknowledged inertia as a barrier to knowledge sharing, access, and utilisation, and making it harder for them to innovate. 


\section{Resource rigidity (T2.1)}

Restricted knowledge access and organisational bureaucracy are identified as means of maintaining authority and ensuring resource dependency for new initiatives. National strategy and policy further augments resource dependency favouring initiatives promoted at the national level.

\section{Restricted Knowledge Access (T2.1.1)}

Knowledge access reduces organisational inertia; higher knowledge access is associated with a higher KM practices adoption. The participants illustrated that public sector employees resist change to protect their authority. In most cases, this authority prevents other employees from accessing knowledge to innovate, thereby reinforcing organisational inertia. In this context, several participants highlighted restricted knowledge access as:

I think, the more the organisation facilitates knowledge and data access, the more we will be able to lead change internally...But unfortunately, knowledge is not openly accessed by all the organisation employees. I think reason behind that is the organisational traditional mind-set that still believe that any type of information inside a public sector organisation should remind confidential Another challenge is the data access, you know, we are a public organisation following standard operating procedures for data security reasons

\section{National Strategy and Policy (T2.1.2)}

The government's strategy and policy dictate the direction adopted by public sector organisations. Government organisations are not empowered to direct resources towards changes 
not explicitly aligned with the national strategy. This behaviour discourages innovation and leads to inertia as echoed by several informants:

Usually, when you work in a public sector organisation, your strategy policies and regulation must be according to one adopted by your government We will revise all of our internal strategies to contribute toward their [national] objectives and future goals

\section{Organisational Bureaucracy (T2.1.3)}

The public sector organisation should focus on minimising bureaucratic procedures and facilitating flexibility in terms of knowledge access, decision-making, and authority delegation.

Several participants highlighted the organisation's bureaucratic procedures as a source of inertia:

[We have] many challenges, listen, we work in a public sector organisation, and like any other organisation in this sector there is centralisation in decision making and processes change approvals., I just can't change internal policy without permission from my higher management. If it happened to request a change, this may take months till the decision-makers meet, discuss the request and approve it or reject it Unfortunately, we can't make the decision as manager, since we have to follow long processes of permission requests when we decide to share some information

\section{Routine rigidity (T2.2)}

National culture that emphasises knowledge hoarding and top-down approach is reflected in organisation's internal policies causing routine rigidity. 
National Culture (T2.2.1)

Public sector organisational culture is significantly impacted by the national culture. A national culture based on centralised authority harbours rigidity, knowledge hoarding, secrecy, and distrust within public sector and creates organisational inertia towards KM practices adoption. An executive highlights this as:

...our culture is based on the government national culture, and you cannot drive change inside a public sector organisation, because our culture represents a small part of the whole government culture, which by the way oblige us to align our internal routines and processes with it

\section{Organisation Internal Policies (T2.2.2)}

Organisational internal policies should focus on promoting a knowledge sharing culture and employee empowerment to enable KM practices adoption. Participants revealed internal policies that promoted working in isolation culture, where knowledge sharing is perceived as an extra and onerous task causing routine rigidity, for example:

$\ldots$ it is human nature. People always trying to keep their knowledge for themselves...I think upgrading our internal policies at the level of knowledge access and building new policies to improve the use of knowledge would solve these problems

In our daily work, there is much paperwork that we need to deal with. Therefore, asking us other tasks like sharing knowledge, or attending knowledge management training inside or outside the organisation is perceived as an extra duty that we need to handle 


\subsection{Organisational Culture (T3)}

Organisational culture and its role in reducing the impact of organisational inertia on KM practices adoption were assessed. Data revealed 5 cultural sub-themes (T3.1 to T3.5, Table 2) categorised under adhocracy and clan cultural archetypes (Cameron and Quinn 2006). Organisational culture is shown to be a focal point being positively affected by transformational leadership, KM adoption, and external factors themes, and in turn facilitating reduction of inertia towards a higher KM practices adoption.

Adhocracy Culture (T3.1)

Participants referred to public sector organisational culture in terms of central decision-making that hampers innovation and employee empowerment. The participants also point to how innovation and knowledge sharing values can help reduce organisational inertia. The values of empowerment, innovation, and knowledge culture are categorised under adhocracy culture (Cameron and Quinn 2006).

\section{Employee Empowerment (T3.1.1)}

The public sector's organisational culture places emphasis on centralised control that impacts knowledge access by impeding free flow of information (Handzic and Agahari 2004). Informants elaborated that employee empowerment would enable the success of KM practices adoption and reduce organisational inertia, for example:

KM practices and initiatives suffer from the internal authority of decision-making; we would love to share knowledge with everyone, inside and outside our organisation 
There is also an obvious impact from the UAE national strategy 2020 that aims to build and develop knowledge-based organisations in the public sector

All seniors at all the organisation management levels are requested to promote, encourage and support any individual or team initiatives that would drive value to our public sector services

\section{Innovation Culture (T3.1.2)}

The interviewees referred to innovation culture as a facilitator of KM practices and a driver of change. Bommert (2010) posits innovation culture in public sector organisations requires employees to have more control and accountability of their work. The participants pointed public sector organisations should become more flexible in terms of decision-making processes and encourage bottom-up innovation, for example:

We utilise our knowledge in driving the organisation innovation wheel forward, managers were asked on different occasions to spread the culture of innovation and involving their employees in driving innovation forward, by using knowledge and technology

\section{Knowledge Culture (T3.1.3)}

The public sector should focus on building knowledge culture and promoting KM practices as an integral part of the organisational culture (Raza and Awang 2020). An organisation that adopts knowledge culture invests in building positive employee perception and learning from past experiences expressed as: 
If the organisation promoted $\mathrm{KM}$ as part of our internal culture, the employees' perception will totally change

Knowledge in [the] organisation should be like an infinite loop you where we create knowledge, share it, utilise it, and create new knowledge

\section{Clan Culture (T3.2)}

Participants discussed values of employee loyalty, supportive social context, and effective employees' relationship epitomizing a clan culture. This is perceived as reducing inertia and enabling change.

\section{Organisation Loyalty (T3.2.1)}

The participants highlighted promoting organisational loyalty among employees to enhance KM practices adoption. This was self-evident from the following quote from a strategic level manager:

We need to develop a culture that promotes organisation loyalty if we managed to promote this loyalty among the organisation employees. I'm sure that all of them will respond positively to any initiative that they perceive as contributing to the organisation's overall mission, and not only the KM practices. Organisation loyalty is very important if we want to drive change

Social Context and Employees' relationship (T3.2.2)

The interviews highlighted team members who are well connected within the organisation can develop and maintain the social context for effective knowledge sharing and creation. The following quote by one top manager is instructive: 
People share their experiences and know-how with others if they have strong social ties with each other. They share because they are socially connected, and they have good relationships

\subsection{Senior Executives' Transformational Leadership Traits (T4)}

The leadership traits of senior executives and their role in changing organisational culture, minimising inertia, and delivering successful KM practices adoption were ascertained. Data revealed five themes (T4.1 to T4.5, Table 2). All participants stated that senior executives play a key role in driving change by promoting KM practices and reducing organisational inertia. Transformation leadership traits help in positively effecting organizational culture through motivating and rewarding employees to share knowledge, developing a vision, ensuring knowledge access, and building trust.

\section{Drive Change (T4.1)}

The participants perceived senior executives have the authority and power to facilitate change such as enabling information access, employee empowerment, and participatory decisionmaking. To endure change, senior management support and commitment is required to enable individuals to adjust their daily routines incorporating new knowledge and novel ways of working (Burke 2011). For example:

As top management, we play an important role in driving change among our teams for efficiency, and innovation, through encouragement, punishment, motivation, and recognition 


\section{Encouragement (T4.2)}

The responses revealed that most managers encourage employees to adopt KM practices by actively participating in knowledge sharing. This encouragement not only enables new knowledge creation but also allows adoption of a new knowledge culture driving KM practices adoption. Referring to this point, affirmed by all the interviewees, a middle manager underline:

The senior executive should encourage our organisation people to share knowledge; they can even measure it, by how much, and how often I have contributed to the organisation's knowledge base or even at the level of my team, and then factor it into my yearly performance evaluations

\section{Involvement (T4.3)}

Senior executives should work towards employee participation in decisions related to knowledge initiatives to ensure higher levels of adoption. An operations level manager elaborated:

I believe that the senior executive should work more on involving us in the decisions related to KM strategies and project[s]. They can ask their management team to develop a chain of communication between us and them, so we can contribute with suggestions and ideas to improve the initiative and they will be sure that the decision is made as a collective expression of what all parties think

\section{Motivation (T4.4)}

Motivation provides an immediate need for satisfaction (Fontana and Frey 2000). The interviewees stressed the role of senior executives in motivating employees to facilitate 
generation and transfer of tacit knowledge and contributing to the organisation's KM practices, for example:

I think the executives should focus on motivating their management teams and employees to exchange knowledge and adopting the best KM practices inside the organisation

Trust (T4.5)

During the interviews, the researcher found that participants referred to trust building as a key task of senior executives. The employees who adopted KM practices needed to build a high level of trust on two levels: first, with the employees working at the same level and, second, with the senior executives. With regards to the latter, employees build their trust based on actions than promises. One interviewee explained as:

I will share knowledge only with the people and the colleagues I trust, and I have been working with them for a long time. I will not share it with the new joiner. But in today's competitive job marketplace, you only keep your position because of what you know, not because you share your knowledge

\subsection{External Factors (T5)}

The results of content analysis of documents from multiple sources validate participants' responses and point to the poor deployment of KM practices inside the organisation at all levels. The public sector's decision centrality and bureaucracy influences organisational agility for change. All participants echoed that public sector organisations would lag in KM practices 
adoption unless external factors like political leadership and national change agenda help foster culture change and provide resources ( $\mathrm{T} 5$, Table 2 ) expressed as:

It doesn't matter, either you are a senior manager or not, driving change inside our organisation will always follow the laws and the procedures of the government regulation framework, we can only force a change in line with these policies and procedures. I think, our involvement in change will always be limited to the government framework and strategic visions, we cannot break rules and drive distributive change without permission, and we are not a private sector organisation. The problem is that in the public sector organisations it's not easy to access all the information that you may need due to the internal policies and regulations that are following the higher government instructions Driving change will always remain in the boundaries of the public sector formal rules and procedures. You should ask the policy makers to drive change at the level of the general regulation so we can drive it forward I believe if you really want to change a public sector organisation, you will need to start from the head. I mean to start from the top government hierarchy, if the national culture will have focused on implementing knowledge...then the change at the bottom of the government hierarchy will be easier [Knowledge strategy] plan will serve of course in line of the government plans and aims

In addition to directly helping reduce resource and routine rigidity through national culture and a national strategy, external factors were also shown to positively impact organisational culture towards higher KM practices adoption. 


\section{Cross-case Comparisons}

In order to build external validity of our model (Figure 2), we compare our key constructs with six case studies of KM practices adoption discussed in Jennex (2005) and summarised in Table 3. One case study is from the Reserve Bank of New Zealand and the other five are from large private sector organisations, Infosys Limited, Nestle USA, Colgate-Palmolive, Xerox, and ChevronTexaco. Similar to our findings, two cases (Reserve Bank of New Zealand and Infosys Limited) are focussed on external factors. They discuss staff attrition and loss of institutional knowledge as a key driver for KM practices adoption. External factors in these two cases are discussed in terms of macro-economic factors such as globalisation, economic reforms, and technological development leading to staff attrition and competitive climate. This contrasts with our findings where external factors (political leadership and national culture) in public sector have a direct impact on KM adoption and organisational culture. It can be argued effect of external factors in private sector (and quasi-private) are indirect and mediated through macro-economic outcomes as a result of political agendas of several states than a single culture or administration. Other four cases (Nestle USA, Colgate-Palmolive, Xerox, and Chevron-Texaco) are focussed on internal factors and discuss a need for process standardisation and technological infrastructure building to support KM sharing as key drivers.

Inertia in private sector is discussed in three cases (Reserve Bank of New Zealand, Nestle USA, Chevron-Texaco) in terms of weak project management practices, e.g., stakeholder engagement and requirements management, resulting in employee resistance and amplified by status quo bias. In contrast, in our study we observe that public sector organisational inertia is embedded in the bureaucracy and institutional memory of the organisation. 
Table 3: Cross-case comparison with private/quasi-private sector KM adoption implementations

\begin{tabular}{|c|c|c|c|c|c|c|}
\hline \begin{tabular}{|l|} 
Case \\
Organisation
\end{tabular} & Context & \begin{tabular}{|l|} 
Organisational \\
Inertia
\end{tabular} & \begin{tabular}{|l|} 
Transformational \\
Leadership
\end{tabular} & $\begin{array}{l}\text { Organisational } \\
\text { Culture }\end{array}$ & $\begin{array}{l}\text { External } \\
\text { factors }\end{array}$ & KM Practices \\
\hline $\begin{array}{l}\text { Reserve Bank } \\
\text { of New } \\
\text { Zealand } \\
(\text { Jennex 2005, } \\
211-34)\end{array}$ & $\begin{array}{l}\text { As the New } \\
\text { Zealand's central } \\
\text { bank, a knowledge } \\
\text { intensive organisation } \\
\text { that requires a range } \\
\text { of specialist skills not } \\
\text { readily available in } \\
\text { the NZ labour market. } \\
\text { With an average } \\
\text { employee lifespan of } \\
9 \text { years, employee } \\
\text { attrition leads to } \\
\text { enterprise knowledge } \\
\text { loss and recognized } \\
\text { as a key imperative } \\
\text { for KM practices } \\
\text { adoption. }\end{array}$ & \begin{tabular}{|l|} 
Discussed in \\
terms of status \\
quo bias and \\
routine rigidity.
\end{tabular} & $\begin{array}{l}\text { Transformational } \\
\text { leadership is } \\
\text { explicated through } \\
\text { a strong corporate } \\
\text { vision, leadership } \\
\text { by example. }\end{array}$ & \begin{tabular}{|l|} 
Culture change \\
adopting \\
knowledge \\
sharing and \\
increasing \\
opportunities for \\
collaboration \\
recognised as a \\
key imperative \\
for success. \\
Thus, \\
recognising \\
development of \\
a clan culture to \\
enable KM \\
practices \\
adoption.
\end{tabular} & $\begin{array}{l}\text { Globalisation } \\
\text { and } \\
\text { technological } \\
\text { development } \\
\text { leading to } \\
\text { higher staff } \\
\text { departures. }\end{array}$ & $\begin{array}{l}\text { KM strategy developed } \\
\text { across three pillars: culture, } \\
\text { structure, and } \\
\text { infrastructure. } \\
\text { Development of a } \\
\text { Knowledge Services Group } \\
\text { to lead the initiative while } \\
\text { also encouraging bottom-up } \\
\text { community of practice for } \\
\text { cultural change. } \\
\text { KM infrastructure focussed } \\
\text { on building knowledge } \\
\text { repositories and access. } \\
\text { Focus on building KM } \\
\text { practices as a core } \\
\text { organisational competency } \\
\text { through recruitment and } \\
\text { training. }\end{array}$ \\
\hline $\begin{array}{l}\text { Infosys } \\
\text { Limited }\end{array}$ & $\begin{array}{l}\text { An Indian } \\
\text { multinational IT } \\
\text { consulting firm } \\
\text { started in } 1981 \text { as an }\end{array}$ & & \begin{tabular}{|l|} 
Transformational \\
leadership \\
exhibited through a \\
strong vision,
\end{tabular} & $\begin{array}{l}\text { Adhocracy and } \\
\text { clan culture } \\
\text { characterised by } \\
\text { flexibility, }\end{array}$ & \begin{tabular}{|l|} 
Initial \\
growth \\
propelled by \\
the economic
\end{tabular} & $\begin{array}{l}\text { KM strategy focussed on } \\
\text { explicit knowledge sharing. }\end{array}$ \\
\hline
\end{tabular}




\begin{tabular}{|c|c|c|c|c|c|c|}
\hline \begin{tabular}{|l|} 
Case \\
Organisation
\end{tabular} & Context & \begin{tabular}{|l|} 
Organisational \\
Inertia
\end{tabular} & $\begin{array}{l}\text { Transformational } \\
\text { Leadership }\end{array}$ & $\begin{array}{l}\text { Organisational } \\
\text { Culture }\end{array}$ & $\begin{array}{l}\text { External } \\
\text { factors }\end{array}$ & KM Practices \\
\hline \begin{tabular}{|l|} 
(Jennex 2005, \\
$289-314)$
\end{tabular} & $\begin{array}{l}\text { offshore software } \\
\text { service provider and } \\
\text { evolving into a global } \\
\text { IT and business } \\
\text { consulting } \\
\text { powerhouse. KM } \\
\text { practices, developing } \\
\text { intellectual resources } \\
\text { and innovating core } \\
\text { processes were } \\
\text { recognised as a key } \\
\text { strategic imperative } \\
\text { by Infosys' leadership } \\
\text { to retain personnel } \\
\text { and market share } \\
\text { while competing } \\
\text { globally. }\end{array}$ & & $\begin{array}{l}\text { leading by } \\
\text { example, integrity } \\
\text { and transparency in } \\
\text { decision-making, } \\
\text { and pursuit of } \\
\text { excellence. }\end{array}$ & $\begin{array}{l}\text { employee } \\
\text { empowerment, } \\
\text { open culture, } \\
\text { building leaders. }\end{array}$ & $\begin{array}{l}\text { reforms and } \\
\text { liberalisation } \\
\text { of 1990s. As } \\
\text { well as } \\
\text { competition } \\
\text { with other } \\
\text { global } \\
\text { consulting } \\
\text { companies } \\
\text { for personnel } \\
\text { and clients } \\
\text { both } \\
\text { internally } \\
\text { and globally. }\end{array}$ & $\begin{array}{l}\text { Creation and development } \\
\text { based on developing a } \\
\text { knowledge taxonomy and a } \\
\text { distributed architecture. } \\
\text { The technology and KM } \\
\text { applications were } \\
\text { developed in-house. } \\
\text { Sharing and utilisation was } \\
\text { encouraged through } \\
\text { monetary incentive } \\
\text { schemes of currency units } \\
\text { derived by quality and } \\
\text { reviews. }\end{array}$ \\
\hline \begin{tabular}{|l|} 
Nestle USA \\
$($ Jennex 2005, \\
$235-48)$
\end{tabular} & \begin{tabular}{|l} 
Following \\
consolidation of \\
several independent \\
brands in 1991, \\
achieving economies \\
of scale and common \\
practices was \\
recognised as \\
imperative strategy.
\end{tabular} & \begin{tabular}{|l|} 
Employee \\
resistance and \\
status-quo bias \\
to new \\
processes and \\
systems.
\end{tabular} & & & & $\begin{array}{l}\text { KM strategy focussed on } \\
\text { process standardisation } \\
\text { with implementation of an } \\
\text { ERP system. } \\
\text { Benefits realisation from } \\
\text { reduced inventory and } \\
\text { improvement of supply- } \\
\text { chain processes with } \\
\text { millions in savings. }\end{array}$ \\
\hline
\end{tabular}




\begin{tabular}{|c|c|c|c|c|c|c|}
\hline \begin{tabular}{|l} 
Case \\
Organisation
\end{tabular} & Context & $\begin{array}{l}\text { Organisational } \\
\text { Inertia }\end{array}$ & $\begin{array}{l}\text { Transformational } \\
\text { Leadership }\end{array}$ & $\begin{array}{l}\text { Organisational } \\
\text { Culture }\end{array}$ & $\begin{array}{l}\text { External } \\
\text { factors }\end{array}$ & KM Practices \\
\hline \begin{tabular}{|l} 
Colgate- \\
Palmolive \\
(Jennex 2005, \\
$235-48)$
\end{tabular} & $\begin{array}{l}\text { Consolidation of data } \\
\text { across several } \\
\text { disparate legacy } \\
\text { systems to improve } \\
\text { information flow and } \\
\text { efficiency. }\end{array}$ & & & & & $\begin{array}{l}\text { KM strategy focussed on } \\
\text { ERP implementation. } \\
\text { Benefits realisation through } \\
\text { millions in savings with } \\
\text { reduced working capital } \\
\text { and efficient inventory } \\
\text { management. }\end{array}$ \\
\hline $\begin{array}{l}\text { Xerox } \\
(\text { Jennex 2005, } \\
235-48)\end{array}$ & $\begin{array}{l}\text { Problems because of } \\
\text { lack of experience } \\
\text { sharing among a } \\
\text { global workforce of } \\
\text { printer maintenance } \\
\text { employees. }\end{array}$ & & & & & $\begin{array}{l}\text { KM strategy focussed on } \\
\text { improving knowledge } \\
\text { sharing among the global } \\
\text { workforce. } \\
\text { Creation and development } \\
\text { of a database of tips and } \\
\text { recommendations. } \\
\text { Sharing and utilisation } \\
\text { encouraged through a non- } \\
\text { monetary community } \\
\text { recognition system. }\end{array}$ \\
\hline $\begin{array}{l}\text { Chevron- } \\
\text { Texaco } \\
\text { (Jennex 2005, } \\
235-48)\end{array}$ & $\begin{array}{l}\text { Following several } \\
\text { mergers and } \\
\text { scrapping of old } \\
\text { legacy systems, } \\
\text { inefficiencies } \\
\text { resulting from use of }\end{array}$ & $\begin{array}{l}\text { Routine rigidity } \\
\text { and resistance } \\
\text { from } \\
\text { employees to } \\
\text { adopt new } \\
\text { processes. }\end{array}$ & & & & $\begin{array}{l}\text { KM strategy focussed on } \\
\text { consolidating knowledge } \\
\text { resources and standardised } \\
\text { business practices using a } \\
\text { new Enterprise Reliability }\end{array}$ \\
\hline
\end{tabular}




\begin{tabular}{|c|c|c|c|c|c|c|}
\hline \begin{tabular}{|l|} 
Case \\
Organisation
\end{tabular} & Context & $\begin{array}{l}\text { Organisational } \\
\text { Inertia }\end{array}$ & $\begin{array}{l}\text { Transformational } \\
\text { Leadership }\end{array}$ & $\begin{array}{l}\text { Organisational } \\
\text { Culture }\end{array}$ & $\begin{array}{l}\text { External } \\
\text { factors }\end{array}$ & KM Practices \\
\hline & $\begin{array}{l}\text { disparate information } \\
\text { management systems } \\
\text { at each refinery. }\end{array}$ & & & & & $\begin{array}{l}\text { Management System } \\
\text { (ERMS). } \\
\text { Utilisation and benefits } \\
\text { realised by the ability to } \\
\text { deal with reoccurring } \\
\text { equipment failures in early } \\
\text { stages. }\end{array}$ \\
\hline
\end{tabular}


Transformational leadership and organisational culture discussed in two cases (Reserve Bank of New Zealand and Infosys Limited) concurs with our findings and the broader KM literature (Boateng et al., 2016; López-Nicolás and Meroño-Cerdán, 2011). Transformational leadership is demonstrated through leading by example, building trust and transparency, and driving change. Organisational culture that supports clan and adhocracy values is discussed as key in successful implementation of KM practices.

KM practices adoption themes are discussed to varying degrees in each of the case studies, but prior research lacks an integrated process approach developed in this paper. Knowledge strategy is discussed in all cases; knowledge creation and development are discussed in terms of explicit knowledge (Reserve Bank of New Zealand and Infosys Limited, Xerox) or as means of consolidating disparate data sources and tactical knowledge (Nestle USA, ColgatePalmolive, and Chevron-Texaco). KM Systems and Technology themes are at the forefront of most KM practices discussion ranging from in-house built applications (Reserve Bank of New Zealand, Infosys Limited, and Xerox) to implementation of enterprise resource planning software (Nestle USA, Colgate-Palmolive, and Chevron-Texaco). Knowledge sharing and utilisation is discussed in terms of monetary awards (Infosys Limited), community recognition of expertise (Xerox) or as a core organisational capability (Reserve Bank of New Zealand). Technology focussed implementations discuss benefits realisation through process efficiencies and cost savings (Nestle USA, Colgate-Palmolive, and Chevron-Texaco).

The above cross-case comparison provides several insights on our analysis and results compared to private sector KM practices adoption. First, similar transformation leadership and organisational culture themes are present in most of $\mathrm{KM}$ practices adoption irrespective of the sector and industry. Second, organisational inertia resulting from bureaucracy and external 
factors such as political leadership and national culture are unique to public sector organisations and their effect needs to be carefully considered in public sector environments. Third, private sector KM implementations has generally taken a technologically focused approach while public sector, and increasingly service based industries, being knowledge intensive need to take a broader organisational and change management perspective as proposed by our process model (Figure 3).

\section{Discussion and Contributions}

This study explored the phenomenon of KM practices in public sector, the role of organisational inertia and the perceived importance of organisational culture and senior executive leadership in reducing this inertia. The study's contribution is discussed in two sub-sections, theoretical and managerial implications.

\subsection{Theoretical Implications}

The objective of this research was to explore how organisational inertia impacts KM practices adoption and the role of organisational culture and transformational leadership in moderating this relationship. The results support seminal theories discussed under literature review with contextual nuances from in-depth exploration of the phenomenon. Supporting Clark (2005)'s contention, we find that resource and routine rigidity has a negative impact on KM practices adoption, a radical change initiative. We find support for Schein's (1992) conception of core values as drivers of individual and group behaviour, as influenced significantly by UAE's collectivist culture. Furthermore, our results corroborate transformation leadership traits being key drivers of change as hypothesised by Burns (1978) and Kotter (1995). Thus, within the context of UAE, we find that clan and adhocracy cultural values (Cameron and Quinn 2006) and 
senior executive's transformational leadership traits mediate the negative relationship of inertia on KM practices adoption. The cross-case comparison of this paper's public sector organisation with private/quasi-private sector KM adoption implementations shows interesting findings. This study shows that public sector KM adoption is influenced by both internal and external factors, where national change agenda and political leadership are key drivers of change.

The key theoretical contribution of this study is the conceptual model (Figure 2) showing the relationships between the four constructs explored in the case study. Using this conceptual model and cross-case comparisons (Table 3), we develop four propositions for further testing.

Corroborating the population ecology theory (Hannan and Freeman 1984), unequivocal voice of participants points to bureaucracy, authority bounded by the rules and procedures, and a national culture of uncertainty avoidance and power distance inducing resource and routine rigidity and inhibiting KM practices adoption. The strong institutional character of public sector organisations inhibiting radical change concurs with other studies in differing contexts, e.g. Australia (Parker 2000). The results show that organisational inertia in the form of resource and routine rigidity has a negative impact on KM practices adoption. Thus, our first proposition states:

P1. Organisational inertia in the form of resource and routine rigidity negatively impacts $K M$ practices adoption in public sector organisations.

Adopting a rational adaptation theoretical framework, the results show organisational inertia is perceived to be countered through external and internal factors.

Externally, developing a national policy towards KM adoption conducive of supporting a knowledge culture is essential. Organisational adaptation driven by an external policy goal can be viewed as teleological motor in play (Van de Ven and Poole 1995). Technological advances 
and pressures from external stakeholders and customers are pushing public sector organisations to adopt digital solutions to KM problems.

Internally, organisational culture with favourable social context and employee loyalty was found to have a positive impact on KM practices adoption by decreasing inertia. This clan culture highlights the Middle East context on collectivism while also providing evidence of the increasing influence of Western business practices with individualistic traits of autonomy and empowerment, associated with adhocracy culture, considered by the participants as drivers of change. Thus, our second proposition states:

P2. Organisational culture based on clan and adhocracy values reduces organisational inertia and positively impacts KM practices adoption in public sector organisations.

The literature review suggests transformational leadership traits are key in influencing employee's affective commitment to change and shaping the organisational culture (Van der Voet, Kuipers, and Groeneveld 2016; Fernandez and Rainey 2006; Kotter 1995). The study affirms transformational leadership's role in enabling change in the public sector organisations supporting our proposition. Leaders drive organisational transformation by reducing inertia through building trust, encouraging and involving employees, and personifying change themselves. Thus, our third proposition states:

P3. Senior executives' transformational leadership traits reduce organisational inertia and positively impacts KM practices adoption in public sector organisations.

Data analysis also revealed organisational culture as the focal point corroborating Schein (2006)'s core values as the drivers of visible organisational activities. Organisational culture was shown to mediate the effect of transformational leadership and external factors on KM practices adoption. Furthermore, the study uncovered a virtuous cycle between organisational culture and 
KM practices adoption that can be viewed from the perspective of a lifecycle motor (Van de Ven and Poole 1995) and comprises a key contribution of this study. Thus, our fourth proposition states:

P4. Organisational culture mediates the effect of transformation leadership and external factors on KM practices adoption in public sector organisations.

\subsection{Managerial Implications}

Public sector organisations are ecosystems consisting of central government, local administration bodies, agencies, and quasi-governmental organisations. Entities within this ecosystem collaborate, exchange knowledge to achieve their goal of serving citizens; thus, highlighting the importance of KM practices. KM practices adoption starts with policy reforms towards development of a knowledge culture. In consonance with the impact of external factors, we contend UAE being a collectivistic culture that respects authority (UAE 2020), change needs to be adopted at the national-governmental level that will obligate the public sector to follow suit and develop new policies and procedures to support a knowledge culture.

Public sector organisations should develop an entrepreneurial and open learning environment that encourages knowledge access and sharing between employees at all levels (Willem \& Buelens, 2007) whilst acknowledging their contributions and loyalty as embedded cultural motivators. Knowledge sharing in public sector organisations, although hampered by inertia and rigidity, information technology plays a key role in enabling change (Yang and Maxwell, 2011). The study shows transformation leadership traits can help engender this entrepreneurial and supportive environment and should be sought after in leadership recruitment.

The virtuous cycle between organisational culture and $\mathrm{KM}$ practices adoption postulates to a self-sustaining mechanism. An initial thrust to counter organisational inertia through 
political will, technological advances and transformational leadership leads to early wins ensuing a positive feedback loop towards higher adoption. This cycle is developed into a process model for KM practices adoption in the following section.

\subsection{Process Model for KM Practices Adoption in the Public Sector}

To ensure effective implementation of the findings by the UAE public sector, we have developed a guiding process model (Figure 3). The model consists of a teleology motor driven by the policy goal and two lifecycle motors driven by change drivers (Van de Ven and Poole 1995). The model requires a national policy change to ensure resources are appropriately assigned and leadership is empowered to facilitate change. 
Figure 3: KM Adoption Process Model

Starting point

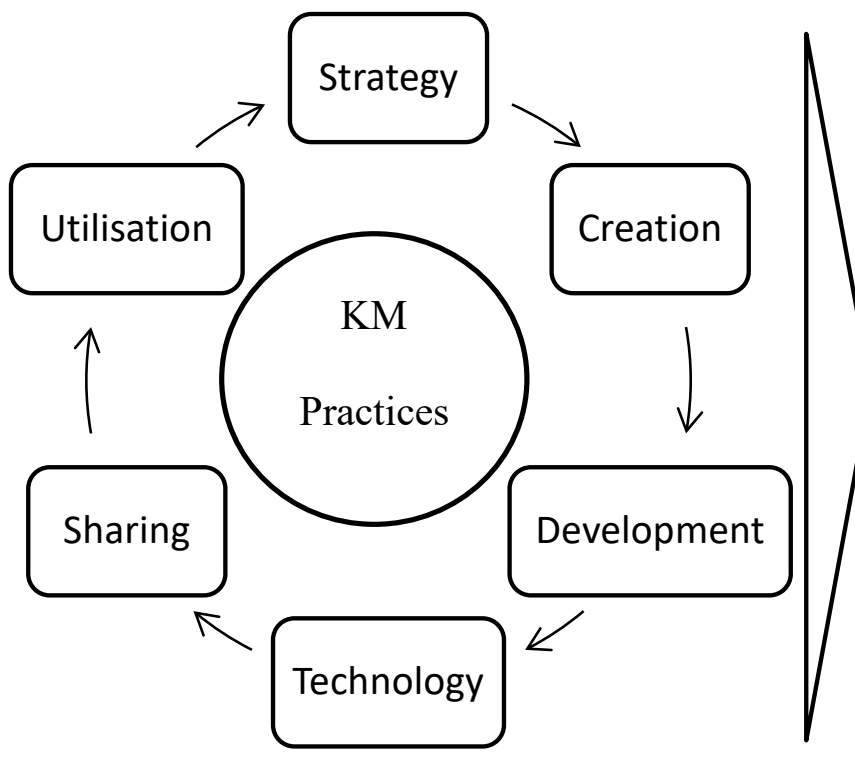

Change drivers

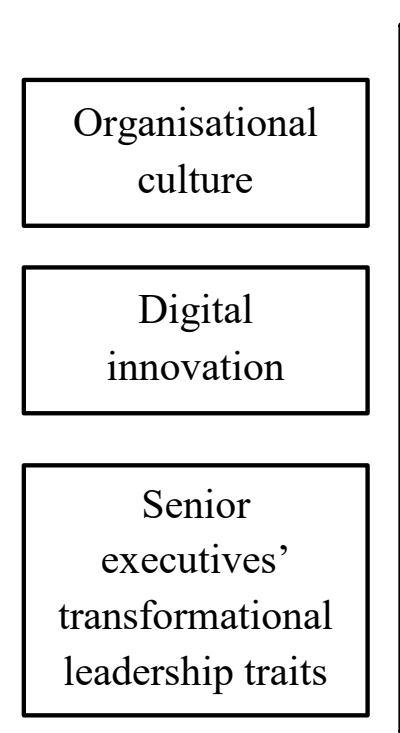

Initial outcome

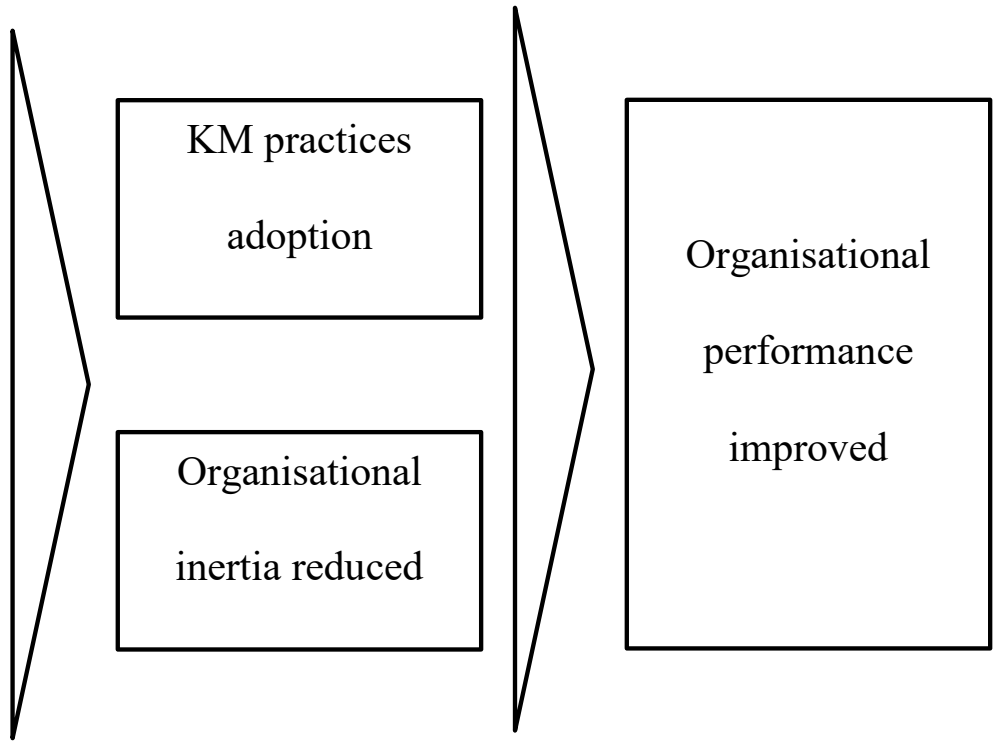

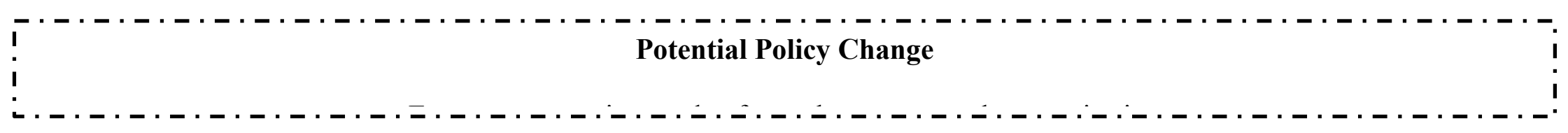




\section{The KM Practices Phase}

In this phase, management establishes an end-goal driven through policy change at the national level and focuses on KM practices processes of strategy, creation, development, technology, sharing, and utilisation. The management reviews existing practices or develops a new KM strategy in line with the organisation's objectives. The strategy should address requirements for knowledge creation and ensure technology is available for knowledge flow to enhance sharing and utilisation (Júnior et al. 2020). Information technology enables public sector organisations to become effective in knowledge access, creation and sharing

\section{The Change Drivers}

The change drivers comprising of cultural change, technological advances and leadership skills are vital for KM practices adoption by reducing organisational inertia and driving each lifecycle phase. In cultural change, management should focus on promoting a new knowledge culture promoting bottom-up innovation and changing the mindset from hierarchy to employee empowerment. Information technology advances and digital innovation play a fundamental role in transforming public sector organisations into digital economies, which is especially true in the current Covid-19 pandemic era (Kromidha and Córdoba-Pachón, 2017). Transformation leadership traits are essential for driving radical change to institutionalised culture and requires employee involvement, motivation, and rewards.

\section{The Initial Outcome Phase}

In this first lifecycle phase, the organisation's management should monitor KM strategy implementation and success. This can be achieved through piloting changes, measuring employee effective commitment, and the number of achieved KPIs. In case of negative 
results, management needs to revisit existing policies and leadership and revise the KM strategy. Thus, a lifecycle approach allows for learning from both positive and negative feedback initiating a virtuous cycle with organisational culture change.

\section{The Final Outcome Phase}

This is the final lifecycle phase where management should start seeing performance improvements at both the operational and financial level. There is an obvious time lag between implementation of the process model and realisation of results.

\section{Conclusion}

The study inductively develops a new conceptual model between KM practices adoption, organisational inertia, organisational culture, and senior executives' leadership traits in the public sector context. The results suggest that organisational culture and senior executives' transformational leadership moderate the negative relationship between organisational inertia and KM practices adoption. The study confirms a strong institutional character of public sector organisations requiring a central policy fostering KM practices at the national level. Furthermore, we find that despite UAE's initiatives to drive change a knowledge culture, the influence of national culture and traditions of collectivism still dominates individuals' values and makes the change process challenging. Finally, information technology plays a key role in enabling knowledge creation, access, adoption and sharing in public sector organisations.

Organisational inertia is a result of Weberian bureaucracy established with the objective of sustaining transparency and consistency in services. However, the growing demand for public sector to be fiscally lean and meet diverse stakeholders' needs is challenging the bureaucracy to be agile, technologically advanced, responsive, and KM 
practices adopters. The current Covid-19 pandemic has forced public sector organisations to adopt digital innovations to cater to its customers and external stakeholders. The study presents insights into developing a knowledge culture through transformational leadership to bring forth an open knowledge sharing cultural change. We suggest that KM practices need to be embedded in the public sector's organisational culture and assigned as senior executives' responsibilities. Organisation culture was shown to mediate the effect of external factors and transformational leadership on KM practices adoption. Furthermore, the virtuous cycle between KM adoption and organisational culture leads to a two-stage process model for KM practices adoption.

\subsection{Limitations and future research opportunities}

The limitations of the study present new opportunities for future research in both knowledge management and public administration fields. First, the research was carried out in one public sector organisation operating in the UAE education sector. There is a need for future research in other public sector organisations and sectors within UAE (or Middle Eastern countries with similar culture). Second, adopting a qualitative methodology ensured in-depth exploration of KM adoption phenomenon within one organisation at the cost of generalisability of the results. Hence, future researchers need to consider testing the conceptual model and the four propositions in other contexts and geographical settings to enhance the generalisability of the results. We suggest quantitative and mixed-method studies to further increase external validity of the results and test the relationships between the constructs. Third, it is premature to assume that the reasons behind organisational inertia and the KM practices in the public sector are consistent. Not all public sector organisations are the same, employees' perceptions are different, and the causes of organisational inertia could be different from one 
organisation to another. Therefore, it is expected that other researchers will consider additional variables for future research considerations, including but not limited to institutional corruption and ethics, regulatory oversight, market dynamics, organisational politics etc.

\section{References}

Abass, Fakhar, Mazhar Hayat, Aamir Shahzad, and Adnan Riaz. 2011. "Analysis of Knowledge Management in the Public Sector of Pakistan." European Journal of Social Sciences 19:471.

Adeinat, I. M., and F.H. Abdulfatah. 2019. "Organizational culture and knowledge management processes: case study in a public university." VINE Journal of Information and Knowledge Management Systems 49 (1):35-53.

Al Ahbabi, Sultan Ali, Sanjay Kumar Singh, Sreejith Balasubramanian, and Sanjaya Singh Gaur. 2019. "Employee perception of impact of knowledge management processes on public sector performance." Journal of Knowledge Management.

Al-Ammary, Jaflah Hassan. 2008. "Knowledge management strategic alignment in the banking sector at the Gulf Cooperation Council (GCC) Countries." Murdoch University.

Al-Khouri, Ali M. 2014. "Fusing knowledge management into the public sector: a review of the field and the case of the emirates identity authority." Journal of Knowledge Management, Economics and Information Technology 4 (3):1-89.

Albino, V., A. C. Garavelli, and M. Gorgoglione. 2004. "Organization and technology in knowledge transfer." Benchmarking: An International Journal 11 (6):584600.

Andrews, Rhys, George A. Boyne, and Gareth Enticott. 2006. "Performance failure in the public sector - Misfortune or mismanagement?" Public Management Review 8 (2):273-96.

Ann Hazlett, Shirley, Rodney McAdam, and Victor Beggs. 2008. "An exploratory study of knowledge flows: A case study of Public Sector Procurement." Total Quality Management 19 (1-2):57-66.

Ardichvili, Alexandre, Martin Maurer, Wei Li, Tim Wentling, and Reed Stuedemann. 2006. "Cultural influences on knowledge sharing through online communities of practice." Journal of Knowledge Management.

Arora, E. 2011. "Knowledge management in public sector." Researchers World, 2(1), pp.165-171.

Ashok, Mona, Marc Day, and Rajneesh Narula. 2018. "Buyer (dis)satisfaction and process innovation: The case of information technology services provision." Industrial Marketing Management 68:132-44.

Ashok, Mona, Rajneesh Narula, and Andrea Martinez-Noya. 2014. "End-user collaboration for process innovation in services: The role of internal resources."

Ashok, Mona, Rajneesh Narula, and Andrea Martinez-Noya. 2016. "How do collaboration and investments in knowledge management affect process innovation in services?" Journal of Knowledge Management 20 (5):1004-24. 
Ashworth, R.E., McDermott, A.M. and Currie, G., 2019. Theorizing from qualitative research in public administration: Plurality through a combination of rigor and richness. Journal of public administration research and theory, 29(2), pp.318333.

Bannister, F. and Connolly, R., 2020. The future ain't what it used to be: Forecasting the impact of ICT on the public sphere. Government Information Quarterly, 37(1), p.101410.

Bansler, Jørgen P., and Erling C. Havn. 2003. "Building community knowledge systems: an empirical study of IT-support for sharing best practices among managers." Knowledge and Process Management 10 (3):156-63.

Bass, Bernard M, Bruce J Avolio, Dong I Jung, and Yair Berson. 2003. "Predicting unit performance by assessing transformational and transactional leadership." Journal of applied psychology 88 (2):207.

Birkinshaw, Julian, and Tony Sheehan. 2002. "Managing the knowledge life cycle." MIT Sloan management review 44 (1):75.

Boateng, Henry, Michael Dzigbordi Dzandu, and Yinshan Tang. 2016. "Knowledge sharing among employees in Ghanaian Industries." Business Information Review 33 (3):145-54.

Bommert, Ben. 2010. "Collaborative innovation in the public sector." International public management review 11 (1):15-33.

Boyne, George. 2002. "Public and Private Management: What's the Difference?" Journal of Management Studies 39:97-122.

Braun, Virginia, and Victoria Clarke. 2006. "Using thematic analysis in psychology." Qualitative research in psychology 3 (2):77-101.

Bryman, A, and E Bell. 2007. "Planning a research project and formulating research questions." Business research methods:75-92.

Bryman, Alan. 2016. Social research methods: Oxford university press.

Burke, ME. 2011. "Knowledge sharing in emerging economies." Library Review.

Burns, James MacGregor. 1978. Leadership. New York: Harper \& Row.

Cameron, K., and R. Quinn. 2006. Diagnosing and Changing Organizational Culture: Based on the Competing Values Framework: Jossey-Bass, San Francisco, CA.

Chawla, Deepak, and Himanshu Joshi. 2010. "Knowledge management initiatives in Indian public and private sector organizations." Journal of Knowledge Management.

Choi, T. and Chandler, S.M., 2020. Knowledge vacuum: An organizational learning dynamic of how e-government innovations fail. Government Information Quarterly, 37(1), p.101416.

Christensen, T., P. Lægreid, P.G. Roness, and K.A. Røvik. 2007. Organization Theory and the Public Sector: Instrument, Culture and Myth: Taylor \& Francis.

Clark, G. Gilbert. 2005. "Unbundling the Structure of Inertia: Resource versus Routine Rigidity." The Academy of Management Journal 48 (5):741.

Cong, X.M., K. Pandya, and Y.Q. Duan. 2004. Knowledge retention in the public sector. Paper presented at the The 5th European Conference on Knowledge Management, Paris.

Cranfield, Desireé Joy, and John Taylor. 2008. "Knowledge management and higher education: A UK case study." Electronic journal of knowledge management 6 (2).

Daymon, Christine, and Immy Holloway. 2011. Qualitative research methods in public relations and marketing communications: London: Routledge. 
Denscombe, M. . 2007. The good research guide. Edited by Boston: McGraw-Hill Education.: Boston: McGraw-Hill Education.

DiMaggio, Paul J, and Walter W Powell. 1983. "The iron cage revisited: Institutional isomorphism and collective rationality in organizational fields." American sociological review: 147-60.

Dimitriades, Zoe S. 2005. "Creating strategic capabilities: organizational learning and knowledge management in the new economy." European Business Review.

Fernandez, Sergio, and Hal G. Rainey. 2006. "Managing Successful Organizational Change in the Public Sector." Public Administration Review 66 (2):168-76.

Fontana, Andrea, and James H Frey. 2000. "The interview: From structured questions to negotiated text." Handbook of qualitative research 2 (6):645-72.

Forum, World Economic. 2016. "The Global Competitiveness Report 2016-2017." In.

Frost, Alan. 2014. A Synthesis of Knowledge Management Failure Factors.

Gatenby, Mark, Chris Rees, Catherine Truss, Kerstin Alfes, and Emma Soane. 2015. "Managing Change, Or Changing Managers? The role of middle managers in UK public service reform." In, 1124-45.

Giampaoli, Daniele, Massimo Ciambotti, and Nick Bontis. 2017. "Knowledge management, problem solving and performance in top Italian firms." Journal of Knowledge Management.

Glaser, B.G., and A.L. Strauss. 1967. The Discovery of Grounded Theory: Strategies for Qualitative Research: Aldine.

Gold, Andrew H, Arvind Malhotra, and Albert H Segars. 2001. "Knowledge management: An organizational capabilities perspective." Journal of management information systems 18 (1):185-214.

Greco, M., M. Grimaldi, and M. Hanandi. 2013. "How to select knowledge management systems: a framework to support managers." International Journal of Engineering Business Management, 5(2), pp.5-12.

Gruman, Jamie A, and Alan M Saks. 2011. "Performance management and employee engagement." Human resource management review 21 (2):123-36.

Gummesson, Evert. 2008. "Quality, service-dominant logic and many-to-many marketing." TQM Journal 20 (2):143.

Handzic, Meliha, and Don Agahari. 2004. "Knowledge sharing culture: A case study." Journal of Information \& Knowledge Management 3 (02):135-42.

Hannan, Michael T, and John Freeman. 1984. "Structural inertia and organizational change." American sociological review:149-64.

Hansen, Jesper Asring, and Signe Pihl-Thingvad. 2019. "Managing employee innovative behaviour through transformational and transactional leadership styles." Public Management Review 21 (6):918-44.

Hartley, Jean, Eva Sørensen, and Jacob Torfing. 2013. "Collaborative Innovation: A Viable Alternative to Market Competition and Organizational Entrepreneurship." Public Administration Review 73 (6):821-30.

Henttonen, Kaisa, Aino Kianto, and Paavo Ritala. 2016. "Knowledge sharing and individual work performance: an empirical study of a public sector organisation." Journal of Knowledge Management.

Hlupic, Vlatka, Athanasia Pouloudi, and George Rzevski. 2002. "Towards an integrated approach to knowledge management:'hard', 'soft'and 'abstract' issues." Knowledge and Process Management 9 (2):90-102.

Holdt Christensen, Peter. 2007. "Knowledge sharing: moving away from the obsession with best practices." Journal of Knowledge Management 11 (1):36-47. 
Hsu, Chin-Lung, and Judy Chuan-Chuan Lin. 2008. "Acceptance of blog usage: The roles of technology acceptance, social influence and knowledge sharing motivation." Information \& Management 45 (1):65-74.

Huysman, Marleen, and Dirk de Wit. 2004. "Practices of managing knowledge sharing: towards a second wave of knowledge management." Knowledge and Process Management 11 (2):81-92.

Huysman, Marleen, and Volker Wulf. 2006. "IT to support knowledge sharing in communities, towards a social capital analysis." Journal of Information Technology (Palgrave Macmillan) 21 (1):40-51.

Ing-Long, $\mathrm{Wu}$, and $\mathrm{Hu}$ Ya-Ping. 2018. "Open innovation based knowledge management implementation: a mediating role of knowledge management design." Journal of Knowledge Management 22 (8):1736-56.

Insights, Hofstede. 2020. "United Arab Emirates." Accessed July 1, 2020. https://www.hofstede-insights.com/country/the-united-arab-emirates/.

Jennex, Murray E. 2005. Case studies in knowledge management: IGI Global.

Julnes, Patria de Lancer, and Marc Holzer. 2001. "Promoting the utilization of performance measures in public organizations: An empirical study of factors affecting adoption and implementation." Public Administration Review 61 (6):693-708.

Júnior, Euro Marques, Jose Alcides Gobbo, Fernando Fukunaga, Roberto Cerchione, and Piera Centobelli. 2020. "Use of knowledge management systems: analysis of the strategies of Brazilian small and medium enterprises." Journal of Knowledge Management.

Kasim, Raja Suzana Raja. 2008. "The relationship of knowledge management practices, competencies and the organizational performance of government departments in Malaysia." International Journal of Social and Human Sciences 2 (12):740-6.

Kattel, R., A. Cepilovs, W. Drechsler, T. Kalvet, V. Lember, and P. Tõnurist. 2014. "Public Sector Innovation Indicators: Towards a New Evaluation Framework." In.

Khalifa, Mohamed, and Vanessa Liu. 2003. "Determinants of successful knowledge management programs." Electronic Journal on Knowledge Management 1 (2):103-12.

Kim, Tae Hun, Jae-Nam Lee, Jae Uk Chun, and Izak Benbasat. 2014. "Understanding the effect of knowledge management strategies on knowledge management performance: A contingency perspective." Information \& Management 51 (4):398-416.

King, N., and C. Horrocks. 2010. Interviews in Qualitative Research: SAGE Publications.

Kotter, John P. 1995. "Leading change: Why transformation efforts fail." Harvard Business Review:59-67.

Kromidha, E. and Córdoba-Pachón, J.R., 2017. Discursive Institutionalism for reconciling change and stability in digital innovation public sector projects for development. Government Information Quarterly, 34(1), pp.16-25.

Kuipers, Ben S., Malcolm Higgs, Walter Kickert, Lars Tummers, Jolien Grandia, and Joris Van Der Voet. 2014. "The management of change in public organizations: A literature review." Public Administration 92 (1):1-20.

Leonard-Barton, Dorothy. 1992. "Core capabilities and core rigidities: A paradox in managing new product development." Strategic Management Journal (John Wiley \& Sons, Inc.) 13:111-25. 
López-Nicolás, Carolina, and Ángel L Meroño-Cerdán. 2011. "Strategic knowledge management, innovation and performance." International Journal of Information Management 31 (6):502-9.

Mahoney, Ray. 2000. "Leadership and learning organisations." The Learning Organization 7 (5):241-4.

Misra, DC, Rama Hariharan, and Manie Khaneja. 2003. "E-knowledge management framework for government organizations." Information systems management 20 (2):38-48.

Moffett, Sandra, and Tim Walker. 2015. "Knowledge Management in the Public Sector: UK Case Study Perspectives." In Advances in Knowledge Management, 67-104. Springer.

Moynihan, D.P., 2009. The network governance of crisis response: Case studies of incident command systems. Journal of Public Administration Research and Theory, 19(4), pp.895-915.

Ngah, Rohana, and Kuan Yew Wong. 2020. "Linking knowledge management to competitive strategies of knowledge-based SMEs." The Bottom Line.

Nonaka, Ikujiro. 1994. "A dynamic theory of organizational knowledge creation." Organization Science 5 (1):14-37.

Nonaka, Ikujiro, Mitsuru Kodama, Ayano Hirose, and Florian Kohlbacher. 2014. "Dynamic fractal organizations for promoting knowledge-based transformationA new paradigm for organizational theory." European Management Journal 32 (1):137-46.

Nonaka, Ikujiro, Georg Von Krogh, and Sven Voelpel. 2006. "Organizational knowledge creation theory: Evolutionary paths and future advances." Organization studies 27 (8):1179-208.

OECD. 2002. "Knowledge Management in Education and Learning. Forum Oxford. 1819 March 2002."

OECD. 2003. "Conclusions from the Results of the Survey of Knowledge Management Practices for Ministries/Departments/Agencies of Central Government in OECD Member Countries, 3-4 February 2003."

Osborne, Stephen P, Zoe Radnor, Tony Kinder, and Isabel Vidal. 2015. "The service framework: A public-service-dominant approach to sustainable public services." British Journal of Management 26 (3):424-38.

Park, Sung Min, Hyung Jun Park, and Eun Young Ryu. 2013. "Determinants of Positive Job Attitude and Behaviour in the Asian Work Context: Evidence from Korean central government agencies." Public Management Review 15 (8):1154-84.

Parker, Rachel. 2000. "Organisational culture in the public sector: evidence from six organisations." International Journal of Public Sector Management 13 (2):12541.

Pathak, Buddhi, Mona Ashok, and Yin Leng Tan. 2020. "Value co-destruction: Exploring the role of actors' opportunism in the B2B context." International Journal of Information Management:102093.

Pauleen, David J, Ling-Ling Wu, and Sally Dexter. 2007. "Exploring the relationship between national and organizational culture, and knowledge management." Cross-cultural perspectives on knowledge management:3-19.

Pee, Loo Geok, and Atreyi Kankanhalli. 2016. "Interactions among factors influencing knowledge management in public-sector organizations: A resource-based view." Government Information Quarterly 33 (1):188-99.

Probst, Gilbert, Steffen Raub, and Kai Romhardt. 2000. Managing knowledge: Building blocks for success. Vol. 360: John Wiley \& Sons Chichester. 
Rainey, Hal G, and Barry Bozeman. 2000. "Comparing public and private organizations: Empirical research and the power of the a priori." Journal of public administration research and theory 10 (2):447-70.

Ramalingam, B. 2005. "Implementing knowledge strategies: lessons from international development agencies. In ODI Working Paper (Vol. 244)." In.

Raza, Irfan, and Zainudin Awang. 2020. "Knowledge sharing in multicultural organizations: evidence from Pakistan." Higher Education, Skills and WorkBased Learning.

Ricard, Lykke Margot, Erik Hans Klijn, Jenny M. Lewis, and Tamyko Ysa. 2017. "Assessing public leadership styles for innovation: a comparison of Copenhagen, Rotterdam and Barcelona." Public Management Review 19 (2):134-56.

Richards, S. G. and Duxbury, Linda (2015) Work-Group Knowledge Acquisition in Knowledge Intensive Public-Sector Organizations: An Exploratory Study, Journal of Public Administration Research and Theory, Volume 25, Issue 4, Pages 1247-1277, https://doi.org/10.1093/jopart/muu034

Rosing, Kathrin, Michael Frese, and Andreas Bausch. 2011. "Explaining the heterogeneity of the leadership-innovation relationship: Ambidextrous leadership." The Leadership Quarterly 22 (5):956-74.

Rubin, Herbert J, and Irene S Rubin. 2011. Qualitative interviewing: The art of hearing data: sage.

Rumelt, Richard P. 1995. "Inertia and transformation." In Resource-based and evolutionary theories of the firm: Towards a synthesis, 101-32. Springer.

Rusly, Fariza H., James L. Corner, and Peter Sun. 2012. "Positioning change readiness in knowledge management research." Journal of Knowledge Management 16 (2):329-55.

Samuelson, William, and Richard Zeckhauser. 1988. "Status quo bias in decision making." Journal of risk and uncertainty 1 (1):7-59.

Schein, E.H. 1992. Organizational Culture and Leadership: Jossey-Bass.

Schein, E.H . 2006. Organizational Culture and Leadership: Wiley.

Schraeder, Mike, Rachel S Tears, and Mark H Jordan. 2005. "Organizational culture in public sector organizations." Leadership \& Organization Development Journal.

Schumpeter, Joseph Alois. 1942. Socialism, capitalism and democracy: Harper and Brothers.

Simon, Herbert A. 1972. "Theories of bounded rationality." Decision and organization $1(1): 161-76$.

Simon, Herbert A. 1991. "Bounded rationality and organizational learning." Organization Science 2 (1):125-34.

Smith Elizabeth, A. 2001. "The role of tacit and explicit knowledge in the workplace." Journal of Knowledge Management 5 (4):311-21.

Soo, Christine, Shannon Chen, and Mark G Edwards. 2018. "A Knowledge-Based Approach to Public Value Management: A Case Study of Change Implementation in Disability Services in Western Australia." Australian Journal of Public Administration 77 (2):187-202.

Symon, G., and C. Cassell. 2012. Qualitative Organizational Research: Core Methods and Current Challenges: SAGE Publications.

Taher, Nader Asaad Bin, Vlad Krotov, and Leiser Silva. 2015. "A framework for leading change in the UAE public sector." International Journal of Organizational Analysis. 
Tan, Li Pin, and Kuan Yew Wong. 2015. "Linkage between knowledge management and manufacturing performance: a structural equation modeling approach." Journal of Knowledge Management.

Taylor, Brent, and Rob C. de Loë. 2012. "Conceptualizations of local knowledge in collaborative environmental governance." Geoforum 43 (6):1207-17.

Taylor, W Andrew, and Gillian H Wright. 2004. "Organizational readiness for successful knowledge sharing: Challenges for public sector managers." Information Resources Management Journal (IRMJ) 17 (2):22-37.

Torfing, Jacob. 2019. "Collaborative innovation in the public sector: the argument." Public Management Review 21 (1):1-11.

Tremml, Timo. 2020. "Barriers to entrepreneurship in public enterprises: boards contributing to inertia." Public Management Review:1-26.

UAE. 2020. "UAE Vision 2021." Accessed June 25, 2020. https://www.vision2021.ae/en/home.

UNPAN. 2007. Restoring trust in government through public sector innovations. Paper presented at the 7th Global Forum on Reinventing Government: Building Trust in Government. United Nations, June Vienna, Austria.

Valmohammadi, Changiz, and Mohsen Ahmadi. 2015. "The impact of knowledge management practices on organizational performance." Journal of Enterprise Information Management.

Van de Ven, Andrew H., and Marshall Scott Poole. 1995. "Explaining Development and Change in Organizations." The Academy of Management Review 20 (3):510.

Van der Voet, Joris, Ben S. Kuipers, and Sandra Groeneveld. 2016. "Implementing Change in Public Organizations: The relationship between leadership and affective commitment to change in a public sector context." Public Management Review 18 (6):842-65.

Vestal, Katherine. 2012. "Which Matters: Employee Satisfaction or Employee Engagement?" Nurse Leader 10 (6):10-1.

Wang, Zhining, and Nianxin Wang. 2012. "Knowledge sharing, innovation and firm performance." Expert Systems With Applications 39 (10):8899-908.

Wankhade, Paresh, Geoffrey Heath, and James Radcliffe. 2018. "Cultural change and perpetuation in organisations: evidence from an English emergency ambulance service." Public Management Review 20 (6):923-48.

Waterhouse, Jennifer, and Dianne Lewis. 2004. "Communicating culture change." Public Management Review 6 (3):353-76.

Willem, A., \& Buelens, M. (2007). Knowledge sharing in public sector organizations: The effect of organizational characteristics on interdepartmental knowledge sharing. Journal of public administration research and theory, 17(4), 581-606.

Wright, Bradley E., and Sanjay K. Pandey. 2010. "Transformational Leadership in the Public Sector: Does Structure Matter?" Journal of Public Administration Research and Theory: J-PART 20 (1):75-89.

Yang, Baiyin, Karen E Watkins, and Victoria J Marsick. 2004. "The construct of the learning organization: Dimensions, measurement, and validation." Human resource development quarterly 15 (1):31-55.

Yang, T.M. and Maxwell, T.A., 2011. Information-sharing in public organizations: A literature review of interpersonal, intra-organizational and inter-organizational success factors. Government Information Quarterly, 28(2), pp.164-175.

Yeh, Ying-Jung, Sun-Quae Lai, and Chin-Tsang Ho. 2006. "Knowledge management enablers: a case study." Industrial Management \& Data Systems. 
Yew Wong, Kuan. 2005. "Critical success factors for implementing knowledge management in small and medium enterprises." Industrial Management \& Data Systems 105 (3):261-79.

Yin, Robert K. 2015. Qualitative research from start to finish: Guilford publications.

Zahedi, Mansooreh, Mojtaba Shahin, and Muhammad Ali Babar. 2016. "A systematic review of knowledge sharing challenges and practices in global software development." International Journal of Information Management 36 (6, Part A):995-1019. 